

\section{DISCLAIMER}

This report was prepared as an account of work sponsored by an agency of the United States Government. Neither the United States Government nor any agency Thereof, nor any of their employees, makes any warranty, express or implied, or assumes any legal liability or responsibility for the accuracy, completeness, or usefulness of any information, apparatus, product, or process disclosed, or represents that its use would not infringe privately owned rights. Reference herein to any specific commercial product, process, or service by trade name, trademark, manufacturer, or otherwise does not necessarily constitute or imply its endorsement, recommendation, or favoring by the United States Government or any agency thereof. The views and opinions of authors expressed herein do not necessarily state or reflect those of the United States Government or any agency thereof. 


\section{DISCLAIMER}

Portions of this document may be illegible in electronic image products. Images are produced from the best available original document. 
This report was prepared as an account of work sponsored by the United States Government. Neither the United States nor the United States Department of Energy, nor any of their employees, nor any of their contractors, subcont ractors, or their employees, makes any warranty, express or implied, or assumes any legal liability or responsibility for the accuracy, completeness or usefulness of any information, apparat us, product or process disclosed, or represents that its use would not infringe privately owned rights.

Reference to a company or product name does not imply approval or recommendation of the product by the University of California or the U.S. Department of Energy to the exclusion of others that may be suitable.

Work performed under the auspices of the U.S. Department of Energy by the Lawrence Livermore Laboratory under Contract W-740S-Eng-48. 
UCRL-52970

Distribution Category UC-66

\section{Geothermal energy and the land resource: conflicts and constraints in The Geysers- Calistoga KGRA}

Kerry O'Banion

Charles Hall

Consultants:

Bill Derrenbacher

Environmental Systems Research Institute

Redlands, California

Brian Parker

Lakeport, California

Manuscript date: July 14, 1980

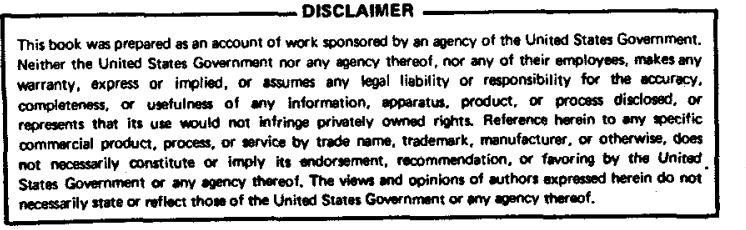

LAWRENCE LIVERMORE LABORATORY

University of California $\bullet$ Livermore, California $\bullet 94550$

Available from: National Technical Information Service $\bullet$ U.S. Department of Commerce

5285 Port Royal Road $\bullet$ Springfield, VA $22161 \bullet \$ 6.00$ per copy $\bullet$ (Microfiche \$3.50) 


\section{FOREWORD}

A preliminary version of this study was published in December 1979. Its purpose was to elicit comments from local agencies and individuals on the numerous assumptions we had to make in the course of our work. This final version incorporates those we received, plus a few other changes:

- Whereas in the preliminary study we spoke only of land-use conflicts, we now discriminate between conflicts and constraints.

- In the preliminary study we only presented the land-use model we developed and the data we compiled; we wanted to get some reaction, particularly local reaction, before drawing any conclusions. In this version we do draw conclusions on the availability and suitability of land for geothermal and habitational development.

- This version also includes a brief survey of the alternative methods for evaluating land suitability and explains why the method we used was chosen.

- This version omits most of the maps contained in the preliminary study, retaining only those germane to our own analysis. This version is therefore much less cumbersome.

- The maps in the preliminary study displaying the potential conflicts of geothermal and residential development are replaced by maps that represent a more thorough analysis of land suitability (Figs. 8-9); in other words, they reflect the conclusions drawn since the preliminary study was released. 


\section{CONTENTS}

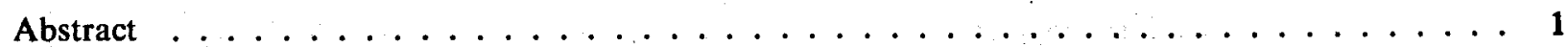

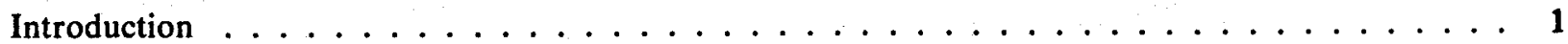

Objectives $\ldots \ldots \ldots \ldots \ldots \ldots \ldots \ldots \ldots \ldots \ldots \ldots \ldots \ldots \ldots$

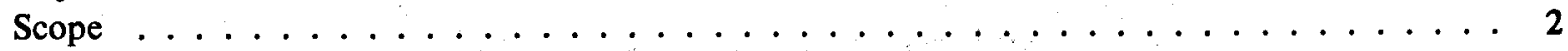

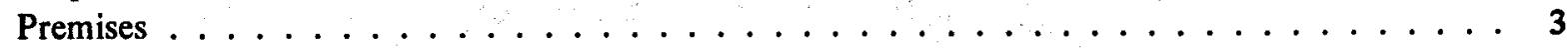

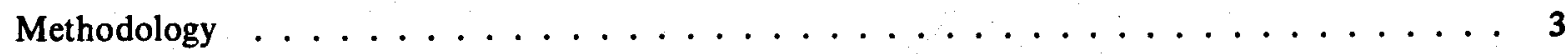

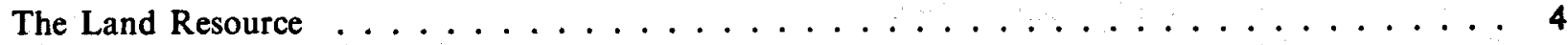

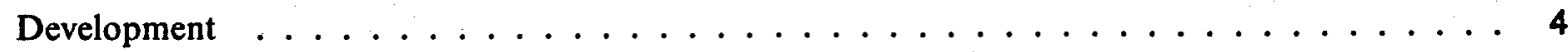

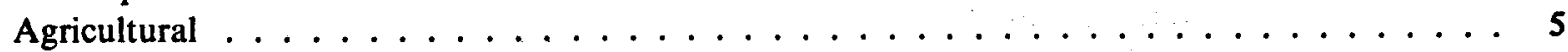

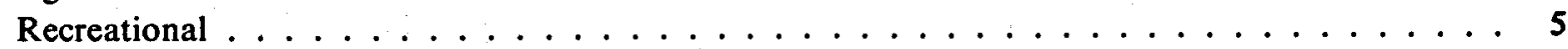

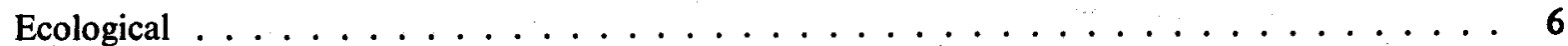

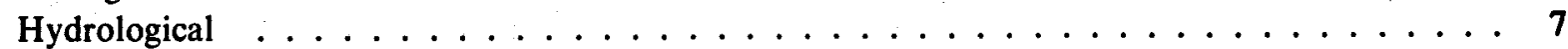

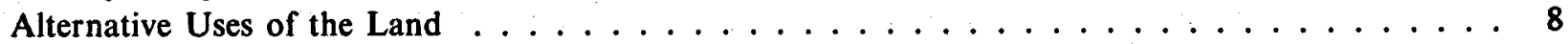

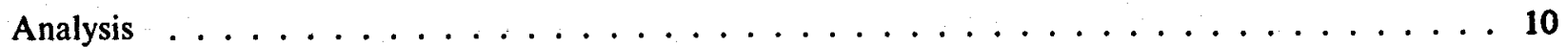

Potential Conflicts and Constraints $\ldots \ldots \ldots \ldots \ldots$

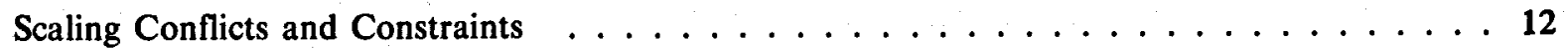

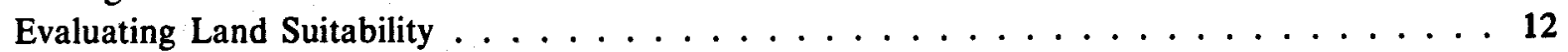

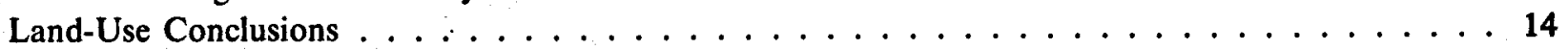

Geothermal Resource Development . . . . . . . . . . . . . . . . . 14

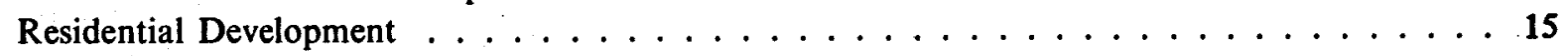

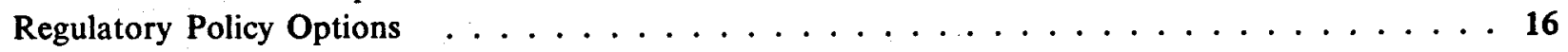

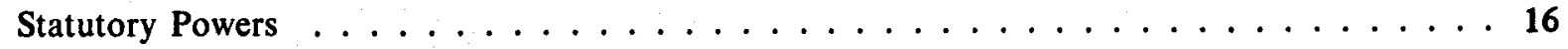

Regulatory Instruments in Use . . . . . . . . . . . . . . . 18

Regulatory Alternatives . . . . . . . . . . . . . . . . . 19

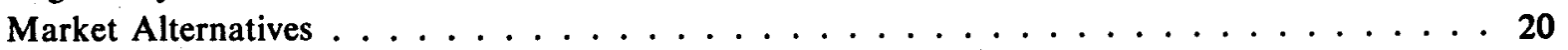

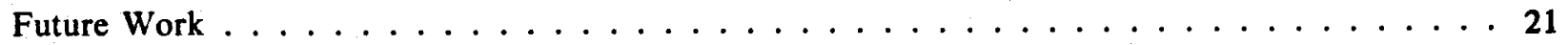

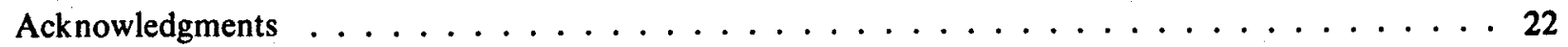

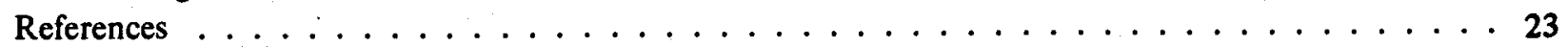

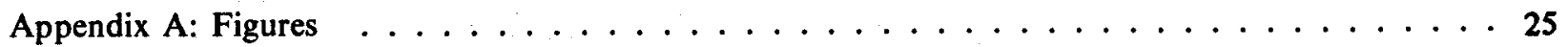




\section{LIST OF TABLES}

1. Matrix of potential land-use conflicts $\ldots \ldots \ldots \ldots \ldots \ldots$

\section{LIST OF ILLUSTRATIONS}

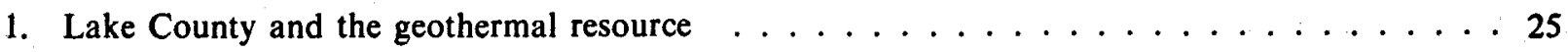

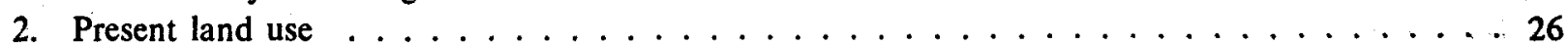

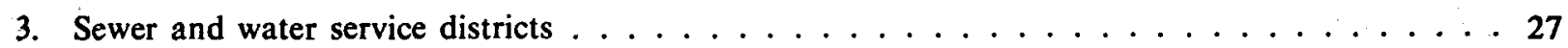

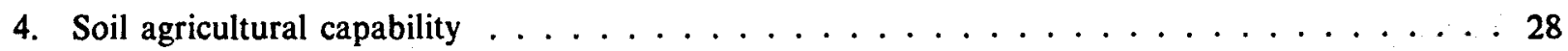

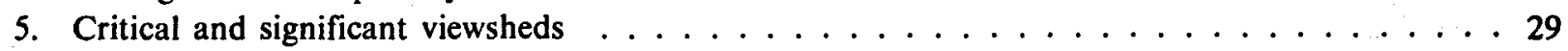

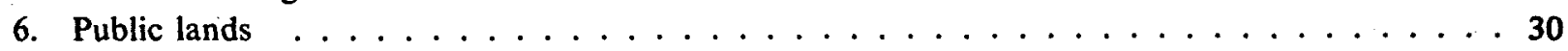

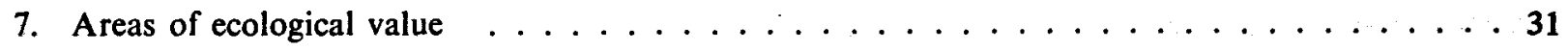

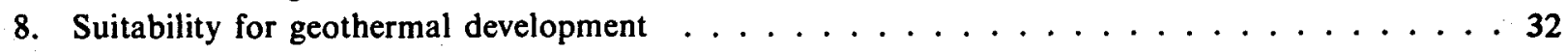

9. Suitability for suburban $/$ urban development $\ldots \ldots \ldots \ldots \ldots \ldots$

10. Diagram of social and economic research program $\ldots \ldots \ldots \ldots \ldots$ 


\title{
Geothermal energy and the land resource: conflicts and constraints in The Geysers-Calistoga KGRA
}

\begin{abstract}
This study of potential land-related impacts of geothermal power development in The Geysers region, one component of the Lawrence Livermore National Laboratory (LLNL)/Lawrence Berkeley National Laboratory (LBNL) socioeconomic program, focuses on Lake County because it has most of the undeveloped resource and the least regulatory capability. We first characterize the land resource in terms of its ecological, hydrological, agricultural, and recreational value; intrinsic natural hazards; and the adequacy of roads and utility systems. Based on those factors, we identify the potential landuse conflicts and constraints that geothermal development may encounter in the region and determine the availability and relative suitability of land for such development. We conclude with a brief review of laws and powers germane to geothermal land-use regulation.

The material in this study will be dovetailed with economic and demographic forecasts, now in preparation, in a combined final report in late 1980 . The final report will include a more detailed analysis of potential socioeconomic impacts and land-use outcomes, as well as an evaluation of policy options to mitigate adverse impacts.
\end{abstract}

\section{INTRODUCTION}

The U.S. Department of Energy (DOE) actively promotes development of geothermal energy in The Geysers-Calistoga Known Geothermal Resource Area (KGRA) through a variety of research programs and the Geothermal Loan Guarantee Program and is thus obligated by law to assess its potential environmental impaots. This particular study is one component of the Socioeconomic Research Program at Lawrence Livermore National Laboratory (LLNL) and Lawrence Berkeley National Laboratory (LBNL), that incorporates economic and demographic as well as landuse consequences and that, in turn, is part of a larger program at the two laboratories to analyze the entire range of impacts from geothermal resource development in this and other regions.

\section{OBJECTIVES}

The objectives of this study are threefold:

- To describe, on a regional scale, the poten- tial land-related constraints and conflicts that confront geothermal resource development,

- To identify policy options to minimize the adverse consequences they indicate, and

- To provide a source of data for local effects assessment and regulatory decisions.

The first and second objectives, for us, relate primarily to the design of DOE policy; but we also expect local agencies and project developers to benefit from at least the first. The last objective recognizes that, particularly in rural areas that often have skeletal bureaucracies, the responsibility of evaluating and granting permits for geothermal use can be a real burden. Since this regulatory load itself is, in part, an impact of DOE programs, we felt obliged to make our study as usable as possible to the counties that are involved. Thus, although we certainly do not presume to make any local decisions, we have compiled data that are relevant to those decisions even though they are not of direct Federal concern. In an effort to share our resources 
with local agencies, we published a preliminary version of this study in December $1979,{ }^{1}$ which included extensive baseline data displayed on individual maps.

The LLL Overview Project found that land-use conflict, along with hydrogen sulfide control, noise control, landslides and soil erosion, and rare and endangered biota, was a high priority issue in The Geysers region. ${ }^{2}$ The purpose of this project was to identify key environmental issues, to establish priorities for those issues, to compile inventories of available data, and to prescribe guidelines for future research. The primary mechanism to identify and set priorities for issues was a series of workshops, involving Federal, State, and local agencies, developers, utilities, and private groups and individuals, as well as LLNL and LBNL. Certainly, since mid-1978 when the Overview Project was completed, land use has become an even more urgent concern. Geothermal resource development has extended over the remote and sparsely populated west slope of the Mayacmas Mountains ridge in Sonoma County to the east slope in Lake County, which forms the west side of Cobb Valley, a residential and resort area. Moreover, at a time when controls over geothermal development are more crucial than ever, the general plans of both Lake and Mendocino Counties have been declared inadequate by the state.

\section{SCOPE}

The Socioeconomic Research Program is designed to include the four counties within the KGRA: Lake, Mendocino, Napa, and Sonoma. However, because of both time and expense, we have concentrated our land-use efforts first on Lake County (Figs. 1, 2), because it has most of the undeveloped resource, will experience the greatest near-term impact, and has the least regulatory capability of the four. Mendocino County may be next highest in priority for study; but unlike Lake County it is not yet subject to much commercial interest in its geothermal resource, and most of its resource is in its least populated area. Sonoma County has an extensively developed field in its easternmost portion; but although future field development may quadruple the energy produced, the relative impacts that are expected are much less than in Lake County. Napa County does not have a large known geothermal resource, and its agriculture-oriented land-use policy will stringently constrain any development.

The need for research in Lake County is even more urgent after the recent decision by the State Attorney General and Office of Planning and Research (OPR) that its general plan, adopted in 1968 , is inadequate. To avoid a formal lawsuit, the County was persuaded to apply for a time extension to revise its general plan to satisfy the State's objections. This application was required to specify interim controls to be enforced during the revision period. ${ }^{3}$ Before this action by the State, a committee of approximately 45 county citizens was formed in late 1978 to begin a comprehensive revision of the general plan. The first step, creation of a set of general land-use policies, has now been completed and the policies presented to the Board of Supervisors. ${ }^{4}$ Although no formal motion of adoption was made, the Board expressed its concurrence with the policies, and we have attributed official status to them in this study.

The subject of land use can be extremely broad, since every type of environmental impact influences and/or is influenced by the use of the land resource. We have, however, limited the scope of this study to the land resource itself or, more precisely, to the physical characteristics that determine its suitability for a given use: its form, geology, hydrology, soil, natural vegetation, and existing infrastructure and use. We include aesthetic quality as a function of the above factors. We do not address issues such as traffic or water or power supply that, while certainly important to the use of a site, are largely exogenous, that is, determined by conditions outside of the site. Note, however, that we do include on-site infrastructure, because a road or a sewer or water line, once in place, becomes as much a feature of the land as the soil or vegetation. We also do not address the issue of emissions from prospective uses, i.e., noise and air and water contaminants; these are covered in detail in other LLNL overview reports and a number of other documents.

Geothermal heat can be used in a wide variety of direct applications as well as in power generation; however, the scope of this report is limited to power generation, for several reasons. For direct use to have any impact on land use, its cost advantage over conventional fuels would have to be large enough to induce new development in the region that otherwise would not occur. The range of potential 
agricultural and industrial uses is so broad and location decisions for each composed of so many factors that to create plausible scenarios for direct use in the region is a major research task in itself. Moreover, cost data on most potential uses are meager at best and strongly influenced by variable factors, such as climate, distance to markets, fuel type and price, etc. On the contrary, power generation, at least in vapor-dominated areas, has been demonstrated to be more than competitive with alternative fuels, and massive development is imminent. Intuitively, however, we expect any impacts of direct use in the near future to be trivial compared to those of power generation, for these reasons: 1) The isolation and poor transportation of Lake County are strong disincentives to any industrial operation. 2) Substituting geothermal heat for fuel is, as a rule, cost effective only from shallow wells; the deep wells required in much of The Geysers region are far too expensiye to be undertaken for direct use only. ${ }^{5}$ 3) The amount of land consumed by even a large number of direct users would be only a fraction of the enormous amount consumed by power generation, because of the relative amounts of energy involved. (The $1700 \mathrm{MW}_{\mathrm{e}}$ already existing, under construction, or sited in the region would provide the electrical needs of an urban area of about $1,700,000$ people.)

\section{PREMISES}

Two types of potential impacts are anticipated with the introduction of any new land use, such as geothermal resource development, into a region: constraints and conflicts. We define constraints as potential impacts that can be mitigated at least in part: soil erosion, wildlife, landslide, etc. We include inadequate infrastructure, namely road, sewer, and water systems, in this category. Conflicts, on the other hand, arise when a site has value for more than one use, and those uses are not compatible.

This dichotomy is reflected in the two premises on which our study is based:

- The suitability of the land for a given use is a function of its location and natural and infrastructural conditions (constraints), and

- The use of land for one activity may preclude or degrade its suitability for others (conflicts).

The first premise is obvious: the more we can match uses with the lands most suitable for them, the lower costs we incur to resolve structural problems, ameliorate hazards, etc. and hence the more optimal our use of resources at both individual and societal levels. But most land is suitable to some extent for more than one use, and to know only its suitability for each respective use is not enough: what, for example; are we to do when the land is equally suitable for two or more uses; or when it is moderately so for a very desirable use, but very suitable for one not so desirable? While some uses can coexist quite nicely, far more often our second premise holds, and a decision must be made on the highest and best use of the land.

Highest and best use is a decision that must be made by those who must live with the consequences, and we do not presume to make decisions for the people of Lake County in our study. We do hope to provide an informational base for those decisions by

- Inventorying the natural and infrastructural features of the land resource,

- Identifying the uses that the land must accommodate to sustain the quality of life in the county,

- Evaluating the land resource for its value for each use, and

- Identifying the potential constraints and conflicts it poses for geothermal energy development.

\section{METHODOLOGY}

Our first step was to identify and define the general functions the land resource must fulfill to sustain life; the second, to develop criteria to evaluate the intrinsic suitability of the land for each function; and the third, to compile the data on which to base those evaluations. Most of the natural and infrastructural data we used are secondary, that is, from already existing sources. References to those sources are given in the section on evaluative criteria. Data on vegetation and land use, however, were interpreted directly from aerial photoimagery. The photoimagery was also used to reconcile and update the secondary data.

We then input the data to a computer by a procedure known as digitizing, which essentially involves tracing features on maps with a device that converts points and lines into numbers ( $x-y$ coordinates). This procedure, although tedious, has real advantages. When the basic data are stored in the 
computer, subroutines can be used to interpret a great deal more from topographic contours. Also, the data can be combined to produce multifactor maps rapidly and cheaply, such as the developmentsuitability maps included in this study. While the data are stored in the polygon form in which they were digitized, for program and display we have converted them to a grid format of 4-ha (10-acre) squares. Besides reducing computer time, this format increases the effectiveness of the maps, both because features smaller than 4 ha are eliminated and because the uniform 200 - by 200 -m grid squares provide a convenient reference dimension.

Based on our evaluative criteria, we then produced a set of maps that depicts the natural and infrastructural features of the county. The complete set of 20 maps was published in our preliminary report ' ${ }^{1}$; in the present report we include only those germane to our own analysis. Obviously, at a 4-ha resolution our maps are suitable only for a macroscale, general plan use. They can not, and we certainly do not intend them to, be used to assess individual projects. The detailed analysis required in an environmental impact statement (EIS) demands both finer resolution and on-site validation. On the contrary, our study is oriented not to individual projects but to the regional impacts of geothermal technology. As such, we envision that it will com- plement and aid incremental, project-by-project decision-making by providing a context for those decisions.

We then broke the general land functions down into more specific land-use types that prevail in Lake County and, in a matrix format (Table 1), identified potential instances of either significant natural or infrastructural constraints, or significant use conflicts with nondevelopment functions.

Meanwhile, based on what we know so far about the steam and hot water resources in Lake County, we began to develop alternative geothermal scenarios and, for each scenario, to project the demographic and economic changes to be expected and, hence, the secondary development to be induced. Since the preliminary land-use report was released, the research team at LBNL has developed high growth and low growth scenarios for the four KGRA counties, and has estimated the direct and indirect population impacts of each scenario. 5 However, the estimates for indirect impacts, namely those resulting from employment induced in sectors other than geothermal, are preliminary only, based on multipliers reported by the Pacific Gas and Electric Company (PG\&E), owner of the existing plants. We are now (June 1980) developing more precise estimates of induced employment, using an input/ output model that contains a geothermal sector.

\section{THE LAND RESOURCE}

We have characterized the Lake County land resource in terms of five general land functions: al),

- Development (geothermal and habitation-

- Agricultural,

- Recreational,

- Ecological,

- Hydrological.

Most of the myriad ways in which man uses, or depends on, the land resource fit in one of these functional designations. In this section, we prescribe criteria by which the intrinsic value of land for each function may be evaluated. (The term land function refers merely to a broad category of use types, such as row crops, field crops, vineyards, orchards, dry pasture, etc., that fit in the category, or function, of agriculture. We prefer the term "function" because it emphasizes the role of the land itself.)

\section{DEVELOPMENT}

The intrinsic suitability of land for development in general is determined by

- Slope,

- Soil load limitations,

- Soil expansion and contraction potential,

- Landslide hazard,

- Earthquake hazard,

- Flood hazard,

- Wildfire hazard,

- Road proximity,

- Sewer proximity, and

- Water system proximity.

Earthquake and landslide hazards depend on a number of conditions that vary from site to site. However, the portions of the Franciscan geologic unit composed of sheared shale and sandstone are 
uniformly unstable, and these we have designated as probable slide-hazard areas at slopes over $15 \%$; two other formations, serpentinite and alluvium, are designated as variable hazard areas, again at slopes greater than $15 \% .^{6}$ We have not directly evaluated seismic hazard; however, since any large earthquake may be expected to induce many landslides on unstable slopes, in this sense the criterion for slide hazard indicates seismic hazard as well.

For wildfire hazard, we adopted a model developed by the California Division of Forestry. It defines hazard as a function of vegetation type, slope, and fire-weather frequency, for which the en: tire county is rated as frequency class III, the most severe. ${ }^{7}$ However, we augmented the model to include both forest- and woodland-vegetation types, that have crown densities of over $40 \%$ and 10 to $40 \%$, respectively, rather than the single woodland type in the original model. Our criterion for flood hazard is the 100-year flood plain.

We have used county policy on infrastructure, which is to ". . develop land that is. . .served by streets, water, sewer and other public services prior to expansion into undeveloped lands." 4 We chose a distance of $1 \mathrm{~km}$ from highways and major roads as the land to which all but very low intensity development should be confined, but we realize that this distance is arbitrary and does not reflect that the value of road proximity is variable. For sewers and water, we simply used the existing service districts (Fig. 3).

\section{AGRICULTURAL}

Although many forms of agriculture are adaptable to a wide range of lands, intensive crop farming is far more sensitive to climate and soil drainage, texture, slope, alkalinity, salinity, and toxicity, namely, those factors reflected in its

- Agricultural capability unit

as designated by the U.S. Soil Conservation Service (SCS) ${ }^{8}$ (Fig. 4).

Fruit and nut production is by far the dominant agricultural sector in Lake County (pears, walnuts, and grapes accounted for $76 \%$ of the total value of agricultural production in 1978) and is a major source of jobs and income. It is county policy to "...preserve and protect the future of agriculture... and to enact zoning to protect agricultural lands and their water resources." 4 We have interpreted agricultural lands as those of SCS capability units I, II, and III. This is broader than the usual definition of prime land as units I and II, but not as broad as SCS's definition of "land suited for cultivation" as units I through IV, IV being "... fairly good land suited to only occasional cultivation and pasture." $8 \mathrm{We}$ include unit III, "... moderately good land with major limitations in use," as agricultural land because a large amount of land now under cultivation in Lake County is unit III, interspersed with soils of units I and II. However, we show it as a distinct category on the map because land most valuable for cultivation, in Lake County as elsewhere, tends also to be the most suitable for development; and where unit III soils exist in isolation, and not interspersed with more valuable soils, the County may be more inclined to permit nonagricultural use.

\section{RECREATIONAL}

In its most inclusive sense, recreation means an antidote to the unpleasant aspects of life, and our definition of this use category covers not only pursuits such as hiking, boating, or lounging at a hot spring, but also the everyday amenity of living in a pleasant rural environment. Unfortunately for our study, people vary so greatly in their ideas on pleasurable activities that no single objective scale of recreational suitability can be devised, at least none that has our confidence. For example, backpackers, hunters, and other users of the more remote, mountainous portions of Lake County would likely rate such country far more valuable than would, say, boaters and anglers who would favor the lake and its shoreline.

However, we could not ignore recreation either, given its importance to, even dominance of, the local economy. Tourism of both transients and the large number of second-home owners and renters is a major source of income to the county; and in-migrant retirees constitute a disproportionately large percentage of the county populace and are evidently its main source of growth. Because both tourists and in-migrants are drawn to Lake County by its recreational amenity, and hence even minor degradation of that amenity could have major consequences for its residents, we felt obligated to identify its most crucial and precious features, namely Clear Lake and its shoreline, the Cobb Valley resort area, designated scenic roads, and public lands. 
A real problem in evaluating the suitability of land for recreation, and its unsuitability for other uses, is identifying the boundary of the feature in question. In this study, we have taken the position that the boundary of the feature is defined by what one can see from within it, or its viewshed, and we do so because of the visual aspect of geothermal resource development. The plumes of vapor and the cuts on the mountainsides, often visible for miles, impart an industrial mood to even otherwise pristine landscapes and would significantly degrade the recreational value of any of the features listed.

Active recreation in Lake County is predominantly water-oriented. The state has forecast that, in 1980, recreational use in the county will exceed five million activity days: $43 \%$ devoted to fishing, $17 \%$ to boating, $12 \%$ to swimming, $9 \%$ each to picnicking and camping, $3 \%$ each to hunting and group activity, and $1 \%$ each to riding and hiking. ${ }^{9}$ Clear Lake is the largest natural lake entirely within California and is the focus for most of this activity and, hence, the location of most recreation-related development. Although a proliferation of badly designed homes, motels, and trailer parks (particularly at its southern end) detracts from the beauty of the lake environs, viewed from a distance or from a less developed portion of its shoreline, the blue-green lake ringed by low mountains remains striking. Almost as striking is Mt. Konocti, an extinct volcano rising almost $3,000 \mathrm{ft}$ above the surface of the lake at its southwest edge. A secondary focus of recreation is Cobb Valley, located along State Route 175 between Cobb Mountain (another extinct volcano) and Boggs Mountain State Forest. Although resorts established around mineral springs flourished in the valley from 1870 to 1930 , most of the resorts have been abandoned or converted to other uses and replaced by motels, some trailer parks, and numerous vacation homes. The quiet forest atmosphere, a sharp contrast to the lake area, is the main attraction of the valley, although hiking and riding are popular. In Lake County, all state highways are designated as scenic roads in the (now invalid) general plan; however, no specific regulations have so far been promulgated.

We defined three categories of recreational features (Fig. 5):

- Critical viewsheds,

- Significant viewsheds, and

- Public lands.

We designated only the Clear Lake viewshed as critical; the reason for our distinction between it and the lower-order significant viewsheds of Cobb Valley and the scenic roads is based on our conviction that, as the focus of tourism in the region, Clear Lake is unique in importance, and its degradation would be catastrophic.

Over half the county is owned by the Federal government (Fig. 6): the northern third of the county is in the Mendocino National Forest, and the U.S. Bureau of Land Management (BLM) has extensive holdings along the east and west edges of the county. The Federal land is mostly remote and invariably mountainous, and it is county policy that it "“. . remain openspace. . . for camping, hiking, nature study, bird watching, and other limited outdoor activities and facilities...".4 Although the county has no actual authority over its use, in fact the only expected competition for this land in the near future is from geothermal resource development. Some of the BLM acreage is already outleased to developers; the Forest Service has not yet outleased any of its land. We have presumed the entire county may at some time be subject to geothermal resource development interest and have included all of it in our study; however, we have excluded Federal and other public lands from consideration for nongeothermal development.

\section{ECOLOGICAL}

At a global, continental, or even regional scale, we presume that the goal of habitat protection is to preserve biotic diversity. Although more tangible benefits to man, such as the derivation of medicinal products or new agricultural hybrids, can be invoked on behalf of wild plants and animals, the main reason for preserving biotic diversity is that, as it decreases, the vulnerability of the world ecosystem increases. That is, the more species that are lost as a result of man's activity, the greater the probability some ecological web that is critical to our survival may be broken.

We have long recognized that, as a rule, the greater the diversity of its vegetation, the more suitable land is for a variety of wildlife. More precisely, wildlife suitability is a function of the number of vegetation types, the diversity of plants within each type, the quantity of land covered by each type, and the extent of interspersion-and, of course, the quality of food, water, and cover each 
type provides. The extent of interspersion is important because most wildlife use more than one vegetation type. Although forest species (e.g., deer, squirrels, raccoons) as a rule derive most of their sustenance from forested areas, most also make significant use of land in shrub and herbaceous cover. However, to species who feed mostly in open land (e.g., rabbits, skunks, quail, sparrow, robins), the proximity of cover is absolutely vital. ${ }^{10}$ Our evaluative criteria for land habitat value, therefore, included

- Plant diversity,

- Relative prevalence of vegetation type,

- Distance to other formations,

- Proximity to water, and

- Areas of special importance.

In Lake County, the narrow strips of riparian woodland exhibit the greatest plant diversity followed in order by mixed conifer-pine forest, chaparral, oak savannah, and pure stands of ponderosa and knobcone pine. Animal diversity within a habitat tends to correlate with plant diversity, and in a recent study of a portion of Lake and Sonoma Counties, this correlation held for the vegetation types listed. ${ }^{11}$ By relative prevalence we simply mean the percentage of acreage in that vegetation type in the entire region. Because we want to maximize the number of types, as a rule, the less abundant a given type, the more important it is that it is preserved.

Our consideration of distance to other formations recognizes that the ecotonal or boundary areas between formations (i.e., forest, chaparral, and savannah) are far more valuable than those more isolated. We have selected $200 \mathrm{~m}$ as the critical distance, a very conservative figure since most open land species do not venture more than 50 to $100 \mathrm{~m}$ from cover; nor are less mobile forest species able to range more than $100 \mathrm{~m}$ or so into the forest and still use chaparral or savannah frequently. ${ }^{10}$ We also recognized the importance of surface water to wildlife by designating land within $300 \mathrm{~m}$ of a yearround stream or other water source as more valuable, again a very conservative figure. However, we realize that the influences of edges and water sources are, by nature, gradients rather than constants.

Riparian vegetation is the only vegetation type both truly scarce and diverse in composition. Although we have not found any comprehensive maps of riparian vegetation for the county, in fact we expect that all of it lies within the aforementioned $600-\mathrm{m}$ wide bands along streams; thus we show only the latter on our maps. Last, we augmented this general model with several areas of special biotic importance (ASBI's) designated by the California Department of Fish and Game' ${ }^{12}$; these include critical habitats (e.g., marshlands) and key wildlife areas (e.g., wintering ranges) as well as habitats of rare species (Fig. 7).

We have not considered aquatic biota directly in the study. At a general level, the aquatic impacts of concern in The Geysers region, mainly sedimentation resulting from soil erosion and releases of toxic substances, are covered by the criteria for erosion potential (see next section) and distance to surface water, respectively. In other words, a policy that excludes development of erosive soils and from areas within $300 \mathrm{~m}$ of water would largely obviate those impacts. Nor have we included any buffer zones for ASBI's, despite their obvious value. Conditions vary so greatly among these areas that we could not devise any universal solution, and to examine each area would be a substantial program in itself. We take some solace in the fact that any ASBI to be affected by proposed development would be analyzed in detail as part of the environmental impact statement or report (EIS/EIR).

\section{HYDROLOGICAL}

The availability, quantity, and quality of water for both human and natural, ecological processes depends not only on the amount of rain but also on the characteristics of the land upon which it falls. Because of the steep topography and the low porosity of underlying geology in most of the county, most streams are intermittent, that is, flow results from runoff alone with no groundwater base flow. Even year-round streams have extremely low flows by the end of the dry season. ${ }^{6}$ In Lake County, at least, the more permeable soils have greater hydrological importance, because most domestic and agricultural water is groundwater, drawn from alluvial basins recharged by percolation from streambeds and rain and by groundwater flow from higher areas. Such soils are also most vulnerable to surface releases of contaminants.

The value of land as undisturbed watershed also increases with soil erodibility in the sense that erodible soils, if disturbed, tend to result in stream sedimentation and, ultimately, in altered flow and 
habitat characteristics. Thus, our criteria for watershed use are

- Hydrologic capability unit, and

- Soil erodibility.

Both are ratings contained in SCS soils reports. ${ }^{8}$ The former criterion is simply a measure of the infiltration rate of surfacial soil.
(The evaluative criteria described in this section, as well as basic environmental conditions, are displayed on individual maps in our preliminary report. ${ }^{1}$ Data sources are referenced on the individual maps. In this report, we have included only those most relevant to our conclusions.)

\section{ALTERNATIVE USES OF THE LAND}

In examining the potential conflicts and constraints posed by the land resource, we limited ourselves to 10 major land use types:

- Nature preserve,

- Low-intensity recreation,

- High-intensity recreation,

- Extensive agriculture,

- Crop agriculture,

- Watershed,

- Rural residential development,

- Low-density residential development,

- Suburban/urban development, and

- Geothermal resource development.

Virtually all of the county is used for one or more of these purposes. We have not included the other uses that make up the miniscule balance, e.g., sand or gravel pits, mines, and garbage dumps for these reasons: We saw no potential for major conflicts between those uses and geothermal resource development, and we felt their inclusion was not as crucial as was the early completion of the study, both because geothermal interest is mounting as a result of continuing increases in costs of other energy resources and because the county has limited time to develop new land-use controls.

\section{Nature Preserve}

Human activity in this category is confined to nonintrusive observation and study. The importance of such activity is secondary to the preservation of the area in its natural form.

\section{Low-Intensity Recreation}

This category includes biking, some picnicking and camping, and educational activity. Access to areas is by foot only, except that equestrian use may be allowed on a one-day basis.

\section{High-Intensity Recreation}

All the above uses are allowed, but at more intensive levels. However, the main distinctions between high- and low-intensity recreation are that both (1) field and water sports and (2) access by boat or car are limited to this recreation category.

\section{Extensive Agriculture}

Grazing on uncultivated land and timber harvesting are included in this category.

\section{Crop Agriculture}

We include all cultivated land in this category, pasture as well as orchards and vineyards.

\section{Watershed}

In this category, we include any land managed to capture rainwater. This is not an exclusive use, however, and may be combined with any other use that would not result in significant devegetation or alteration of water flow or soil permeability.

\section{Rural Residential Development}

Our definition of rural residential use is an average of no more than 1 dwelling unit/4 ha $(10 \mathrm{a})$. But ours is a functional definition and, we believe, more reasonable than more conventional ones that range up to 1 unit/ha or so. At 1 unit/4 ha, as a rule up to $5 \%$ of the land is covered by buildings, paving, and landscaping. At a lower density than this, the land retains at least some of its ecological and hydrological integrity; at densities not far above it, those functions are seriously disrupted. The land becomes more suburban than rural, and most of its recreational amenity is lost.

An average density of 1 unit/4 ha is low enough to permit a mixture of residential development with recreational uses or even natural areas, 
by varying lot sizes from 1 ha ( 2.5 a) to 16 ha ( 40 a) or more. Moreover, as long as lot sizes are not less than 1 ha, development need not be constrained by slope, erosive soils, or fire or landslide hazard. The policy of the county to limit development to sewerand water-serviced areas is stated as a unilateral one; but whether such low intensity development as this is meant to be covered by that policy is not clear. Certainly, water and sewer systems for such areas would be quite expensive. We have presumed that, at an average density of 1 unit/4 ha or lower, the county would permit individual systems in lieu of public systems; this is far more conservative than its present regulations, which permit individual systems on lots as small as 0.4 ha.

\section{Low-Density Residential Development}

At densities greater than an average of 1 unit/4 ha, the landscape acquires a more and more developed character, and the ability to integrate residential with natural or recreational areas decreases markedly until at 1 unit/ha we reach an unmistakably suburban density, at which $15 \%$ or more of the land is covered by buildings, paving, and landscaping. We define low-density residential areas as those having an average density between 1 unit/4 ha and 1 unit/ha.

\section{Suburban/Urban Development}

In this category we have included industrial, sales and service, and institutional uses, as well as residential use at densities greater than 1 unit/ha. This definition is consistent with the Interim Land Use Policy adopted by the county, pending the new General Plan. Although we recognize that large scale, heavy industry can pose impacts that result in greater constraints on its locational options than on other urban uses, this is not germane to Lake County. Because of its isolation, low capacity roads, and lack of rail or air service, it is unlikely that any but small, low-impact industries would be developed in the county, and because the characteristics of such industries would be similar to those of sales and service or institutional uses, we see no need to consider them separately.

\section{Geothermal Resource Development}

We have divided geothermal resource development into two components: the plant and wellfield complex and transmission lines. Because steam to be used to generate electric power cannot be transported more than about $1.6 \mathrm{~km}$ without a prohibitive temperature drop, powerplants can neither be consolidated nor moved far from their associated fields. The areal extent of a well field, in turn, depends on the capacity of the plant, the density of supply wells allowed by the reservoir, and the topography of the area. The larger the powerplant, of course, the more steam is required to maintain a given output and, hence, the more wells must be drilled; the newer plants in The Geysers region each consist of two 55-MW units and require 15 to 25 wells. Well spacing is governed by inherent characteristics of the reservoir; at The Geysers, the average density is 1 well/23 ha. Topography is a factor, because as slope increases, so does the surface area required for development because of the extensive cut and fill involved in road and pad construction. The rugged terrain at The Geysers can require up to twice the acreage required on flat land. 13,14

Of the gross area involved, some 350 to 600 ha/ $100-\mathrm{MW}$ plant, only 7 to $10 \%$ is disturbed: approximately $3 \%$ for well pads, $1 \%$ for the powerplant, $1 \%$ for the main road, and $2 \%$ for secondary roads and steam lines. The steam lines are mounted above ground at heights ranging from 0.15 to more than $3 \mathrm{~m}$; trees and chaparral are removed along the route for about $6 \mathrm{~m}$ on each side of the steam line to protect it from fire. Asphalt- or gravel-surfaced roads run to each well pad; the average width disturbed by main roads is about $15 \mathrm{~m}$ and by secondary roads about $9 \mathrm{~m}$. Each well pad must provide a flat, cleared, and compacted area of at least 0.3 ha. The plant itself requires a flat, paved area of at least 2 ha. In most parts of The Geysers region, the topography must be altered quite extensively to provide level pads of this size; in the upland areas, cuts of over $3 \mathrm{~m}$ are occasionally required. ${ }^{13,14}$

Each generation unit is connected by a transmission line to the nearest or otherwise optimal grid line or load center. All future lines in The Geysers region will be $230 \mathrm{kV}$ and will have rights of way approximately $36 \mathrm{~m}$ wide; however, use of multiple line corridors may decrease the total acreage required, since the distance between the lines will probably be under $18 \mathrm{~m}$. The rights of way are cleared of trees and chaparral, although bridges of coniferous trees across them may be provided to facilitate migration of large animals. ${ }^{13,14}$

We have confined this report to the plant/field complex. Transmission lines involve a multitude of 
landscape types and extend far outside the region, and the set of potential environmental tradeoffs is so large that it is extremely hard to address them generically. We have chosen instead to deal with transmission lines in a separate report, focusing on the visual impacts of alternative routes of a $230-\mathrm{kV}$ line between The Geysers region and the San Francisco Bay area. ${ }^{15}$

\section{ANALYSIS}

The introduction of any new land use, such as geothermal energy development, into a region encounters both constraints and conflicts. We define constraints for a given prospective use as instances when

- A natural feature (soil, vegetation, etc.) of the site indicates a propensity for adverse impact, or

- The infrastructure is inadequate because of proximity or capacity.

Lake County policy confines development to areas adequately served by roads and sewer and water systems, and our study acknowledges that policy for nongeothermal development. ${ }^{4}$ Obviously, it makes fiscal sense to use the existing infrastructure to its full capacity before extending it, and the nonpublic alternatives, namely septic tanks or package plants for sewage disposal and private wells for water, are regulatory burdens for the county as well as potential environmental problems.

We define conflicts as instances when

- The site is very suitable for some other development type, or

- The site is valuable for a nondevelopment function (hydrological, ecological, recreational or cultural, agricultural).

Almost all land is suitable to some extent for more than one use, and thus some potential for conflict always exists. By the same token, even the least constrained land has some potential for adverse impact. Obviously, the mere existence of a potential constraint or conflict $(\mathrm{c} / \mathrm{c})$ of indeterminate significance or magnitude is not by itself an adequate definition of unsuitability; if it were, almost nothing could be built. Identification of a $\mathrm{c} / \mathrm{c}$ is only the first step toward land-use policy. Next, the magnitude or significance of each $\mathrm{c} / \mathrm{c}$ must be measured on some scale of desirability vs undesirability; the scale, however, may be nonquantitative. The scaled values of each $\mathrm{c} / \mathrm{c}$ must then be combined to determine the suitability of the land for each use. Finally, the results for each use must be incorporated into a comprehensive policy.

\section{POTENTIAL CONFLICTS AND CONSTRAINTS}

Table 1 shows the instances in which the coincidence of a land-use type with a natural or infrastructural feature is a potential conflict or constraint. Nature preserves and watersheds are suitable uses for all lands, low-intensity recreation and extensive agriculture are suitable uses for all except ASBI's and riparian areas. Crop agriculture and high-intensity recreation, however, because they involve removal of natural vegetation, conflict with ecotonal areas as well.

The least intensive type of nongeothermal development, rural residential, is restricted only by flood plains, prime agricultural soils, riparian areas, and public lands, the last only because it is county policy to preserve those lands as open space. As the intensity of development increases, the probability of slope failure increases with the percentage of land disturbance and structural load, and the probability of erosion with land disturbance and the percentage of impervious surface. At a suburban/urban intensity, fire hazard also becomes a potential constraint, because of population concentration, as do permeable soils because of the amount of impervious surface involved. As previously explained, only the rural residential category is not limited by infrastructural systems.

Geothermal resource development is constrained by the stability and erodibility of the soil because of the extensive cutting and filling required to build flat pads and roads in this mountainous area. However, because the amount of land covered by impermeable surfaces is insignificant, permeable soils are not a conflict. We indicate prime cropland as a potential conflict because in some instances, the operational layouts of a steamfield and an orchard or vineyard would be incompatible with one another; steam lines and roads are probably the major problems. 


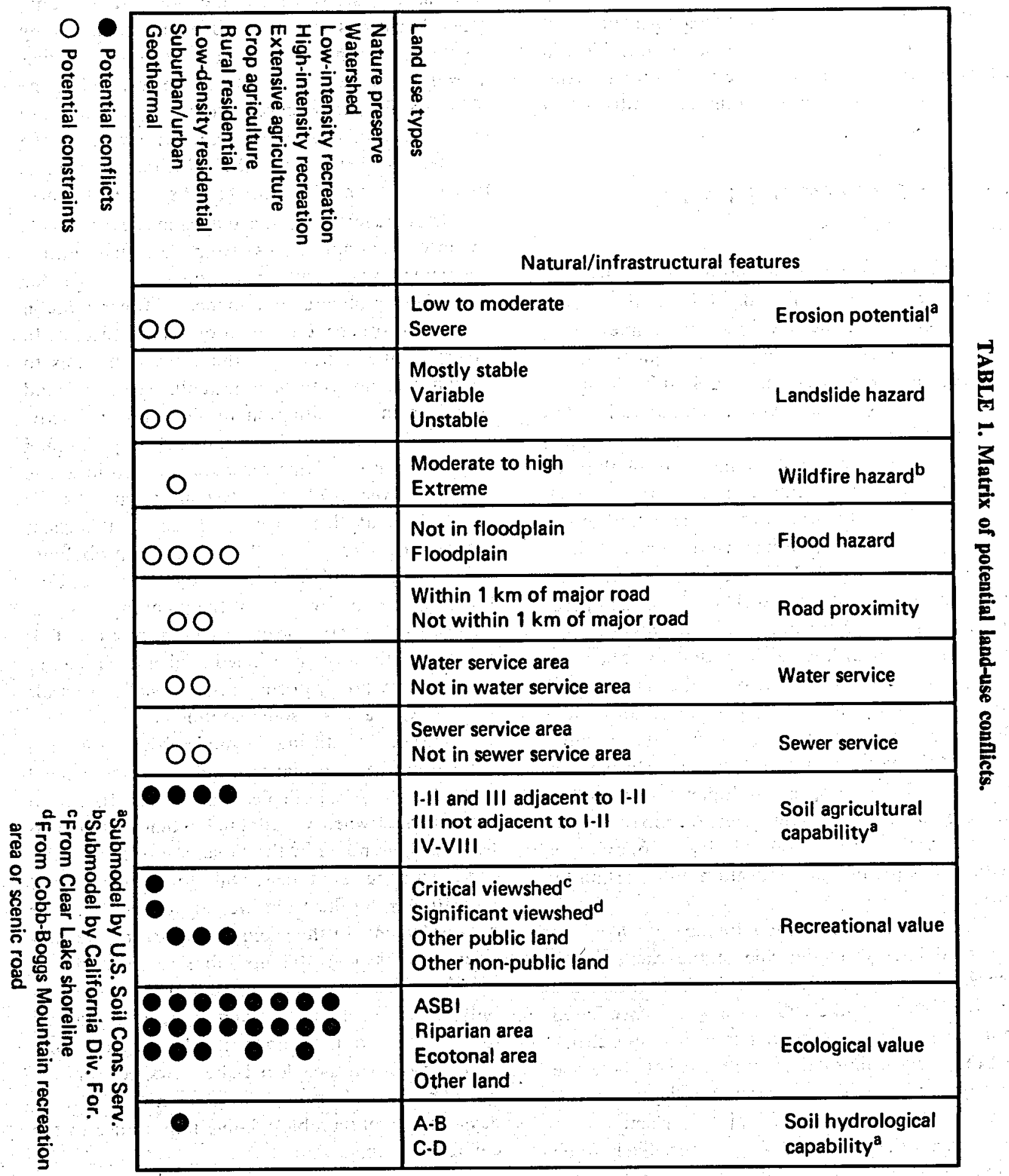


The issue of ecological areas is habitat alteration rather than destruction. Only a minor percentage of land in a plant or field complex is disturbed; however, the roads and steam lines cut it into isolated parcels of land, each of which may not itself be large enough to be viable as a habitat. Also, in many instances the new service roads provide vehicle access to previously remote, undisturbed wilderness.

\section{SCALING CONFLICTS AND CONSTRAINTS}

Any of four types of scales can be used to measure c/c: categorical, ordinal, interval, or ratio. In a categorical scale, the first and simplest type, states or levels of a $\mathrm{c} / \mathrm{c}$ are not quantitatively related, but are only categorized as suitable or unsuitable for a given use. On an ordinal scàle, c/c's are ranked in order of undesirability; for example, in our model, an ASBI is more unsuitable for development than a riparian area, a riparian area more unsuitable than an ecotonal area, and so on. (A categorical scale is, in fact, an ordinal scale having only two values.) Only comparisons $(<,=,>$ ) can be made with ordinal scaled values; the operations $(+,-, \times, \div)$ are not valid. An interval scale differs from an ordinal scale in that its values are relative, not merely comparative, that is, it would convey not only that ASBI's are more unsuitable than riparian or ecotonal areas, but also by how much. Arithmetic operations can be performed on interval-scaled values, but multiplication and division are limited to constant terms. A ratio scale is an interval scale with a nonarbitrary zero point, a feature that permits multiplication and division by variables.

The type of scale used to measure a $\mathrm{c} / \mathrm{c}$ is governed largely by the role of the client in the process. We are convinced that, for both moral and practical reasons, the subjective, preference-based input to a policy study should come from the client, not the analyst: moral, because the client is the one who has to live with the eventual policy; practical, because if the results reflect the client's own preferences, the eventual policy is more likely to be implemented and enforced. The analyst's own preferences may vary significantly with the client's, or, particularly if not a resident of the area, she/he may be unaware of important decision factors.

If the client declines to participate at all, the analyst is quite limited in what she/he can do. If some form of land-use policy exists, the analyst may be able to infer categorical scales from it. In our case, as our study began, the old (1967) county general plan was declared inadequate and invalid by the State. Fortunately, however, a year or so earlier, a group of citizens formed to revise and update the plan; so far, they developed a set of land-use guidelines that was subsequently endorsed by the county. ${ }^{4}$ The existence of the guidelines enabled us to develop our model with at least some confidence.

In some instances, the analyst may even be able to infer ordinal scales from land-use policy augmented by observed conditions, in our case, for example, the obvious dominance of Clear Lake in relation to other recreational or visual features. In other instances, however, the analyst just has to wing it if a study is to be done at all. We often found ourselves in this situation in The Geysers study, because of the virtual absence of a county planning staff while most of our work was done. But at the very least, the prudent analyst must have his/her conclusions at this stage validated by the client before plowing ahead. Otherwise, the probability that the client will trust the study is remote. Fortunately, the chairwoman of the planning commission was able to critique our preliminary study. This input, plus the aforementioned guidelines and a few other county policy documents, enabled us to scale the $\mathrm{c} / \mathrm{c}$ with at least some confidence.

Without venturing beyond observation and deduction (into speculation), we prescribed ordinal scales for all c/c's, as depicted in Table 1. In fact, in the instances when we adopted submodels created by others, as noted in the table, the ordinal scales came with the submodels. Only for ecological and recreational conflicts did we rely entirely on our own judgment. In the ecological category, we considered areas near streams more significant than ecotones because, while an ecotone is important only to resident fauna, a water source is important to all fauna over a far larger area. Under recreation, we distinguished the Clear Lake viewshed from the others because of its much larger number of visitordays and its observable relative importance to the county economy.

\section{EVALUATING LAND SUITABILITY}

Once the individual $\mathrm{c} / \mathrm{c}$ 's are measured, they must be amalgamated into some composite index of 
suitability for the use in question. How the $c / c$ 's are amalgamated, however, is limited by the type of scale used to measure them. Since the operations $(+,-, \times, \div)$ are not valid for categorical values, the methods to combine them are quite restricted. One alternative for categorical values, the conjunctive method, is simply to distinguish sites suitable over all $\mathrm{c} / \mathrm{c}$ 's from those unsuitable for one or more reasons. Unquestionably, this method does identify the best land for a given use; as a rule, however, land with no $\mathrm{c} / \mathrm{c}$ is a minor percentage of the total, and the conjunctive method is unable to discriminate among those comprising the balance.

A more elaborate use of categorical values is a procedure known as the lexicographic method. First, the set of $c / c$ 's are ranked by their respective importance; then, sites are screened for each $\mathrm{c} / \mathrm{c}$ in turn. Those eliminated by the top ranked $\mathrm{c} / \mathrm{c}$ are designated as least suitable, those by the second ranked $c / c$ as next least suitable, and so on. Inarguably, the lexicographic method is easy to administer; unfortunately, it is also simplistic. Only the most important $c / c$ at any site is recognized, while lower order $c / c$ 's are ignored. That is, given four $\mathrm{c} / \mathrm{c}$ 's ranked in order of importance $C_{1}>C_{2}>C_{3}>C_{4}$, a site posing ónly $C_{1}$ would always be designated as less suitable than a site posing $\mathrm{C}_{2}, \mathrm{C}_{3}$, and $\mathrm{C}_{4}$. We think the results obtained by such logic would, in practice, be so often at yariance with what the client perceives intuitively it could not maintain credibility for long.

While ordinal values do provide more detailed information on individual $\mathrm{c} / \mathrm{c}$, they do not provide much of an advantage over categorical values in evaluating composite suitability, because the operations $(+,-, \times, \div)$ remain invalid. About the only improvement one can make in the aforementioned conjunctive and lexicographic procedures is to use ordinal values for one of the $\mathrm{c} / \mathrm{c}$ 's and categorical values for the remainder (conjunctive ranking, lexicographic ranking). The ordinal scaled $\mathrm{c} / \mathrm{c}$ should be the one for which discrimination beyond two values is most significant to the eventual policy.

Using interval scaled values, a client's preferences can be modeled with far more confidence. For one thing, since interval values have relative magnitude, all the $\mathrm{c} / \mathrm{c}$ 's can be normalized to a uniform scale of desirability/undesirability, e.g., 0 to 1.0. This permits use of methods such as the factor profile. In this method, the discrete $\mathrm{c} / \mathrm{c}$ values for each prospective site are compared to those for the other sites, and any site that is dominated by one or more other sites is eliminated; a site dominates another when it is superior in every factor. Pairs of nondominated sites for the use in question are then compared subjectively, for example, is prime agricultural land more suitable than an ecotone located on very erodible soil? This procedure is repeated for all pairs, yielding a rank ordering of sites.

As may be evident from its description, the factor-profile method was devised to select one site from a few alternatives. However, when a whole region is evaluated for suitability, the number of pairwise comparisons required can become inordinately large. Moreover, this kind of judgmental comparison becomes confounding when more than a couple of $c / c$ 's are involved. To deal with a larger number of sites or factors or both, particularly if a computer is to be used to store and manipulate data, a more formal procedure is required, based on some predetermined objective function.

This brings us to a second major advantage of interval scaled values, namely that arithmetic operations are valid. Thus, in what has become the most widespread formal method to evaluate land suitability, each $\mathrm{c} / \mathrm{c}$ can be weighted to denote its relative importance and then the sum of weighted values (SWV) taken to comprise an index of suitability for each site. Unfortunately, this formula is only deceptively simple; for its results to be entirely valid, a number of preconditions must be met: 1) The weight factors must be ratio-scaled. 2) $\mathrm{A}$ weight must represent only the importance of the change in a $\mathrm{c} / \mathrm{c}$ relative to changes in others and must not be influenced by the value of the $c / c .3$ ) The client's order of preference for any two $\mathrm{c} / \mathrm{c}$ 's must not be influenced by the value of any other $c / c$, for example, the relative importance of soil erodibility might be influenced by the value for slope. Fortunately, simple iterative routines can be used to ensure the interval values and weights reduced from the client are valid; unfortunately, they are tedious and require an inordinate amount of time.

Our view toward SWV as a policymaking aid is mixed. On one hand, it is the only method of those described that explicitly considers the relative importance of $c / c$, and thus its results are likely to portray client preferences far more accurately than cruder methods. On the other hand, we are not sure that this advantage compensates for the problems 
one encounters in its execution: 1) It is timeconsuming; the required dialogues with the client(s) can take days. 2) SWV is based on a theory that is conceptually abstruse and can be described only in mathematical terms and diagrams. It is extremely hard to convey, to a client who has no exposure to the field or patience or aptitude for symbolic logic, just how and why the results are obtained. 3) Moreover, the questions used to elicit his/her preferences are hypothetical and do not explicitly involve the alternatives under consideration. Thus, clients have no idea of the consequences of their responses at the time they provide them. This eliminates decision influences outside the model that may otherwise be incorporated into clients' preferences. Unfortunately, models are never perfect, and if legitimate factors are inadvertently excluded the results will seem counterintuitive.

Our use of ordinal scales limited our amalgamation options to the conjunctive and lexicographic methods. However, even were we to overlook the dubious logic of the lexicographic method, we could not use it because it requires more client input than we were able to obtain, namely a ranking of $\mathrm{c} / \mathrm{c}$ 's in order of importance. We were left, then, with the conjunctive ranking method as our best alternative. Again, this method permits ordinal values to be used for one factor, categorical values for the rest.

\section{LAND-USE CONCLUSIONS}

Exploitation of the geothermal resource will result not only in plant or field development, but also in a certain amount of induced housing development. Not only does the industry require a work force of its own who must be housed, but the wages and taxes it pays and the merchandise it buys within the county will induce further development in turn. Thus, a cumulative assessment of land-use impacts must await our completion of demographic and economic forecasts; as previously mentioned, we expect to publish this assessment at the end of 1980. However, at this point we can draw conclusions about the availability and suitability of land for alternative prospective uses.

\section{GEOTHERMAL RESOURCE DEVELOPMENT}

Of the nine $c / c$ 's we identified for geothermal resource development (Table 1), three are constraints and six are conflicts. We have preserved this semantic distinction because, in general, constraints tend to be more amenable to mitigation than conflicts; hence, while most conflicts must be resolved by policy decisions (the highest and best use), constraints can often be adequately dealt with by performance standards. As long as such standards are not so burdensome that they make future development uncompetitive with alternative investments, they have no impact on land use; hence, constraints that can be overcome, by standards that do not make development cost uncompetitive, are not relevant to land-use policy. In The Geysers region, flood, landslide and erosion potential all fall into this category, so we eliminated them from further analysis.

Of the conflicts that remained, two are addressed in Lake County policy. Agriculture is expected to continue as a viable enterprise in the county, and uses incompatible with it are to be excluded from prime land; and geothermal resource development is now prohibited from within $500 \mathrm{ft}$ of streams. Recreational value is not addressed directly; however, since the entire resource area is within one or another secondary viewshed, those viewsheds are not relevant to any decision on relative suitability of land within the resource area, and so they were also eliminated as suitability factors.

The conjunctive ranking procedure for amalgamating factors permits one factor to be scaled ordinally, the rest categorically: Because all c/c groups except "ecological value" contain only one conflict (since significant viewsheds were eliminated) and thus can only be categorical, ecological value became the ordinal factor by default.

Figure 8 shows the distribution of conflicts in the resource area, from which three conclusions are evident:

The vapor-dominated area and the southern half of the liquid-dominated area are quite variegated; 
however, about $50 \%$ of these areas is free of all $c / c$ 's except for secondary viewsheds. Another $25 \%$ is free of all $\mathrm{c} / \mathrm{c}$ 's except for secondary viewsheds and ecotones. Given the locational flexibility of hydrothermal plants (up to $1.6 \mathrm{~km}$ from a given well), even in our high-growth scenario of $2400 \mathrm{MW}_{\mathrm{e}}$, by the year 2000 , land in the first category should be adequate to accommodate all plants required. ${ }^{5}$ Wellpads, roads, and pipelines may infringe on ecotonal and riparian zones; however, compared to that caused by powerplants the land disturbance caused by these features is relatively minor and dispersed and human activity infrequent. Moreover, their impact can be significantly reduced by slant drilling, which permits several wellheads to be grouped on a single pad.

- No hydrothermal development can take place without adverse visual impacts. Almost the entire resource area is within the viewsheds of either Cobb Valley or one or more scenic roads. County policy does not now address the protection of either. However, some limitations for the Cobb Valley area are clearly favored by a significant portion of county residents, composed largely but not exclusively of those who live in the area, and thus any future development may be expected to be controversial in at least this regard.

- The entire northern half of the liquiddominated area poses at least one serious land-use conflict. As well as being within the viewshed of Clear Lake, the area includes the crucial marshlands along the shoreline of the lake and some of the best cropland in the county. From a local perspective, the benefits of hydrothermal development in this area may compare unfavorably with its costs.

\section{RESIDENTIAL DEVELOPMENT}

The suitability of land for residential development is a more complex issue, complicated by such development's variability in form and intensity; by its locational flexibility; and by the proximity of roads and water and sewer lines.

Figure 9 displays $\mathrm{c} / \mathrm{c}$ 's for residential development at an urban/suburban intensity (see Table 1). What is immediately apparent is that areas completely served by infrastructure (see also Fig. 3) do not, in the main, coincide with areas free of other c/c's. Only about 452 ha (1116a), or $0.13 \%$, of undeveloped land poses no $\mathrm{c} / \mathrm{c}$ 's at all (this figure does not include the uncounted number of vacant parcels within developed areas). If, for example, all this land were to be developed at a residential density of 10 units/ha, at the county average of 2.5 persons/ unit it could accommodate 11,160 new residents.

Our preliminary estimates, however, indicate that even with no new geothermal resource development, Lake County would grow by more than this number in the next decade alone. ${ }^{5}$ Since a density much above 10 units/ha is extremely unlikely, it is clear that any population increment induced by geothermal resource development must result in one or more of the following:

- Development of serviced land having one or more natural $c / c$. For fiscal as well as environmental reasons, it is in the county's interest to limit new development to areas now serviced by in-place infrastructure. Unfortunately, in Lake County most undeveloped, serviced areas pose one or more natural $c / c$. Whether the advantage of in-place infrastructure should take precedence over $c / c$ 's at a given site depends on the importance of the $c / c$ 's and to what extent they can be mitigated. However, since constraints tend to be more mitigable than conflicts, land posing only the former is in general more suitable for development.

- Extension or construction of new infrastructure. More than $4 \%$ of the county has no natural $\mathrm{c} / \mathrm{c}$, but lacks one or more type of service. Most of such land is in the sparsely populated southeast portion, but about $0.5 \%$ is adjacent to existing development at the west and southeast ends of the lake; of particular interest is that north of Lakeport, which lacks only water service. Extension of roads or water or sewer lines to accommodate new residents, however, is viable only if the road network, water source, or sewage plant; respectively, can handle the increased load.

- Use of individual services, in lieu of public services. Alternatively, were the county to continue to permit individual septic and water systems, the balance of land with no natural $c / c$ could be developed at minimal public cost. However, to avoid depleting and contaminating groundwater further, the maximum density would have to be much lower than the present 1 unit/0.4 ha. Another alternative to public infrastructure is to require developers to provide the required services for their own developments (e.g., package sewage-treatment plants). However, because the developers must absorb the entire cost of such services and because the 
county must enforce their maintenance, this option tends not to be popular with either group.

- Curtailment of new development. It is within the legitimate power of the county to stop virtually all new development. As long as regulation does not entirely deprive the landowner of its use and is demonstrably based on the public weal, it is almost certain to be upheld by the courts (we deal with this subject in more detail in the next section, under "Statutory Powers: The Taking Question"). Of course, optimal use of the land resource is only one aspect of development regulation. Of comparable importance are the size, composition, and distribution of the citizenry and the private economy; the size and incidence of the tax burden; and the quality and availability of public services. In our cumulative assessment, the above land-use conclusions for both geothermal and residential development will be elaborated into a range of policy options that consider all these dimensions.

\section{REGULATORY POLICY OPTIONS}

While we have reserved any detailed analysis of policy options for the cumulative socioeconomic assessment, the range of options available to local and regional government is constrained by the statutory powers and regulatory instruments they hold, and thus we feel a brief review of those relevant to land use is in order at this point. We have confined the scope of this review to geothermal resource development itself. The means of control over. the more conventional types of development that geothermal energy may induce, such as worker housing, are, we feel, both familiar to most of us and relatively clear. That is, unlike geothermal resource development, control is vested entirely (or almost so) in local governments. Of course, much of what we say, particularly in the section on regulatory alternatives, is germane to all development types.

\section{STATUTORY POWERS}

The California Energy Commission (CEC) now has the "... exclusive power to certify all power-plant sites and related facilities in the state. . in lieu of any permit, certificate, or similar document required by any state, local or regional agency. .." 16 on non-Federal lands. The California Division of Oil and Gas (CDOG) has lead-agency status for exploratory wells, i.e., responsibility for the environmental impact report (EIR), but the county retains the final decision to grant a permit or to impose any conditions on a permit it deems necessary. Moreover, the county retains the same permit authority over production wells; thus, CEC could certify a power-plant site, yet the county could deny a permit to develop the associated steam field. A county that has completed and adopted a geothermal element to its general plan may petition CEC for plant-siting authority and CDOG for leadagency status over exploratory drilling; but Imperial County in southern California is the only county to have adopted a geothermal element to date.

On Federal lands, state and local governments have no actual statutory regulatory power. However, Federal agencies are mandated to make their programs and grants consistent with state, regional, and local plans. ${ }^{17}$ In The Geysers region, BLM has consented that all geothermal resource development activity concerning its outleased lands be governed by the same state and local procedures that prevail on non-Federal land. ${ }^{18}$ Although it is important to note that this arrangement exists by agreement and not by law, we have assumed that it will continue and will extent to National Forest lands as well.

\section{Well-Drilling}

Although The Geysers counties have no direct authority over powerplant or powerline decisions, they can control those decisions indirectly through their authority over well-drilling; in effect, they have a veto power over CED certification, the use of which is presumably to be guided by their respective general plans.

Lake County, however, distinguishes between exploratory and developmental wells in its recently adopted geothermal policy: "Exploratory projects will be considered as separate from developmental projects for the purposes of the Planning Department and the Air Pollution Control District permit 
procedures." 19 In other words, an exploratory project is not to be evaluated on its eventual result, i.e., a producing field and plant, but only on the impacts of the exploratory work itself, a comparatively benign activity.

As we understand it, the issue of exploratory vs developmental work arose in Lake County in an airquality rather than a land-use context. A developer seeking an exploratory permit was required by the air pollution control officer to demonstrate first that the eventual plant/field complex would not violate air-quality standards; his decision was overturned by the Board and the aforementioned policy was enacted. Evidently, the rationale is that 1) a developer should not be forced to bear the costs of analyzing and modeling for full development when exploration may not in fact disclose a resource to justify it, and 2) control of air contaminants is primarily a technological problem, and exploration should not be foreclosed because of impacts that could be abated by some gadget or method yet to be developed. Whatever the merit of this rationale with respect to air quality, the policy poses a dilemma when extended to land use: how and on what grounds can a county allow exploratory work, yet not commit itself to full-scale development?

\section{Power Plants and Related Facilities}

The CEC has complete authority over powerplant and powerline siting: "... a county government would not have power to regulate or prohibit construction of thermal powerplant sites and facilities. . .if they should fall under jurisdiction of the state commission, but the commission must solicit extensive comments and recommendations from county government. . .20

However, the county may petition the CEC for delegation of this authority if:

- The county has adopted a geothermal element to its general plan that conforms to guidelines set by the state. The element must include both a policy framework and specific criteria and regulations to develop the resource and must present the environmental impacts of development in general terms.

- The county has the capability, both technical and physical, to process applications within one year.

- The county can provide for an appropriate legal record of its actions, as well as public notifica- tion for the transcription of all hearings. ${ }^{21}$

However, given that an applicant or any other interested party would have the right to appeal county decisions to the CEC and because the county can exert a large measure of control through its permit authority in any case, we are inclined to concur with the CEC Geothermal Advisory Committee that most counties do not intend to pursue such delegation. $^{21}$

\section{The Taking Question}

Where land has special value for resource extraction, regulations that preclude extraction can reduce the value of the land significantly, particularly where alternative uses are few and marginal. In those instances, land or mineral owners frequently contest such regulations on the grounds that they constitute a taking, i.e., a governmental action whereby the owner of property is deprived of all or most of its beneficial use. To be sure, the U.S. Constitution states "... nor shall private property be taken for public use without just compensation." 22 However, until the late 19th century the idea of taking was limited by court decisions to actual physical seizure; in general, no indirect or consequential damage, including loss of value resulting from regulation, was held to require compensation. However, the direction of the courts was to be changed by Justice Holmes who, in a series of decisions in the period 1890-1920, developed the notion that governmental powers to acquire and to regulate land differed only in degree. This series culminated in 1922 with his now-famous decision in Pennsylvania Coal Company v. Mahon: "The general rule at least is, that while property may be regulated to a certain extent, if regulation goes too far it is recognized as a taking." 23 Based on this general rule, the courts have in subsequent cases adopted a sort of balancing test, weighing the public benefits of regulation against the landowners' loss. As may be imagined, in the absence of any more definitive doctrine than Holmes' rule, interpretations of just what is fair or balanced vary widely from court to court. However, at least two trends of note have emerged.

One is the tendency of the courts to favor regulations that control those uses of land regarded as nuisances; i.e., activities or facilities that impair the health, safety, comfort, or morals of the 
citizenry. The other, particularly evident in the last, post-NEPA decade, is a strong tendency to favor regulations that are state-wide or regional in nature; although the courts are also upholding local regulations fairly consistently, they show an obvious bias toward those having broad multipurpose goals. ${ }^{24}$ One reason may be that the integrity or at least objectivity of a state or regional body is considered much greater than that of the local entity. The latter may be perceived as more prone to legislation for quasiprivate ends-in favor of a hometown developer, for example.

Most land-use regulation contests arise in the state courts, and no state court sees itself as particularly bound by decisions in other states. The Supreme Court of California, however, seems unlikely to hold any regulation invalid under the taking clause and apparently considers the idea of regulatory taking more as a hypothetical than a real possibility. But perhaps more important than actual legal precedent is the myth of the taking clause: a powerful image of the clause as the embodiment of every man's right to buy and use land for a profit. This myth fosters the idea that far less can be done to regulate land use than court decisions in fact permit. The danger, in our minds realized more often than not, is that local governments may fail to exercise the powers they have or back down quickly when contested. ${ }^{24}$ In the case of resource extraction, particularly of geothermal resources, the position of local government is doubly vulnerable, because any regulation that prohibits that use not only devalues the land, but also constrains the resource developer to a far greater extent than is so in development of other types: the developer has almost no recourse to alternative, more suitable plots of land.

As geothermal development extends over the Mayacmas Mountains ridge from the almost uninhabited areas of Sonoma County down into more populated and more sensitive areas of Lake County, we expect the taking argument to be heard more and more from developers as a counter to prospective regulatory decisions and plans. The spectre of eternal litigation may be raised, and a small, poor county like Lake must take this seriously. Nevertheless, it is clear that as long as a regulation or decision does not entirely deprive the landowner of the use of land and is demonstrably based on the general public welfare, it is reasonably certain to be upheld even when land use is severely curtailed, e.g., when geothermal development is prohibited.

\section{REGULATORY INSTRUMENTS IN USE}

\section{Zoning}

Zoning is an exercise of the police power that resides in the state, although in California, as in most states, this exercise is delegated to city and county governments. The state requires that zoning conform with a city or county general plan and prescribes the content of the plan in some detail. As well as a general development policy, the plan must include a set of elements focusing in detail on land use, circulation, housing, resource conservation, open space, noise, safety, seismic safety, and scenic roads. ${ }^{25}$ Other elements may be included at local option. However, the control that the state has over a local general plan is only procedural in nature; that is, it is confined to format, subjects covered, consistency of its parts, and so on. In the case of Lake County, its general plan was held to be inadequate, both because it lacked a safety element and because it contained, in the county's words, "...certain other ambiguities and inconsistencies. ..."3

The power to zone is the power to exclude certain uses of land from prescribed areas and, conversely, confine them to others. In its most basic form, a zoning ordinance consists of a map of the city or county laid out in districts and a list of uses permitted in each, described both by activity type (e.g., residential, industrial) and by quantitative criteria (e.g., density, bulk, floor/area ratio). As well as those uses that are unilaterally permitted or not permitted in a given zone, the ordinance may designate certain other uses as conditionally permitted, that is, subject to additional provisions specific to the site and use in question. The idea is, whereas some activity or facility types can be defined as incompatible per se (e.g., a smelting plant in a residential area) others may or may not be incompatible, depending on their design, environs, or mode of operation (e.g., a nursery in the same area). In Lake County, geothermal drilling is now conditionally permitted in all zones, although the county geothermal regulations do specify minimum distances from hospitals (1 mi); subdivisions, populated areas, and schools $(0.5 \mathrm{mi})$; residences $(500 \mathrm{ft})$; and public roads and the parcel boundary $(100 \mathrm{ft}){ }^{26}$ Thus, beyond these exclusions, permit conditions are presently the only control device over geothermal resource development that the county has, although 
conceivably very sensitive areas might require such extensive conditions to avoid environmental harm that development would be precluded because of cost.

\section{Permit Conditions}

Conditions on geothermal permits in Lake County are presently based on (1) the draft EIR for the project and (2) the county Conditions, Procedures, and Performance Standards for Geothermal Regulation. ${ }^{26}$ The Conditions document, adopted in 1972, is presently being revised; the new version will comprise general development policy, generic conditions for all aspects of development, and performance standards, both general and for sensitive areas. ${ }^{27}$ Preparation of EIR's for well drilling, as we mentioned above, is now administered by CDOG. However, in contrast to the case of plant and powerline siting, we think counties having geothermal resources are far more likely to pursue delegation of this authority, once their geothermal elements are completed. Although no real increase in regulatory power is involved, the counties would gain more control over the quality and veracity of their primary (and frequently only) data source for site-related impacts, the project EIR.

\section{REGULATORY ALTERNATIVES}

\section{Exclusion}

With the few exceptions contained in the geothermal Conditions, exclusion is not presently used in Lake County to control geothermal development: it is conditionally permitted on all lands. Under this arrangement, the county has the advantage of maximum discretion. No site is precluded absolutely, yet every one is subject to individual review and, subsequently, a set of permit conditions tailored to fit its characteristics. The conditions, of course, must be based on policy and criteria determined in advance to ensure equal protection under the law -in the case of Lake County, that policy is stated in the aforementioned Conditions. The problem, however, is that for some sites or impact types, state-of-the-art mitigation is not adequate to prevent significant environmental harm. Consider the visual impact of a plant-field complex on the Clear Lake viewshed, for example. The 1972 Conditions require only that such a development be ...harmonious in appearance with the area and not of obnoxious, undesirable, or unsightly appearance. A landscaping screen shall be installed to the approval of the County Planning Commission.; .All roads shall be constructed in such a manner as not to upset the natural aesthetics of the landscape. ${ }^{26}$

In the most recent (May 1979) draft that we have of the revised geothermal conditions, the language is hardly more precise:

...the operator shall reduce visual impact where feasible, by careful selection of sites. . . The design and construction of facilities shall be conducted such that the facilities will blend into the natural environmental setting of the area by appropriate use of landscaping, vegetation, compatible colors, and minimum profiles. 27

The ambiguity of such policy is not due to a lack of either eloquence or resolve on the county's part; it simply reflects the fact that, presently at least, little can be done to make a geothermal plant unobtrusive, particularly on a grass- or chaparralcovered slope that faces a large body of water. In such situations where a precious resource is involved, the county may want to prohibit geothermal development as the only way to avoid significant damage.

Exclusion of a given use can be promulgated in two ways: by area or by criteria. Exclusion by area simply entails identifying the spatial boundary of a given feature and designating that area in the zoning ordinance to preclude the use in question. Exclusion by criteria, on the other hand, requires only that the feature to be protected be defined in the ordinance text, and compliance with the ordinance must be ascertained on a case-by-case basis. The exclusions prescribed in the Conditions that forbid geothermal development within certain distances of other types of development are examples of this method.

Both have advantages and disadvantages. Exclusion by area is unquestionably easier for both the county and the developer: one only has to glance at a map to know if a given use is or is not prohibited. However, this method can only be as effective as the map is accurate, and it is almost inevitable that the map will omit some features because they are too small to show up, came into existence after the map was created, or simply had not been discovered, as is often the case in remote areas. Such features would be disclosed if an EIR or EIS is prepared, but, 
as a rule, unless they are covered by some other statute the developer is under no legal obligation to preserve them.

\section{Moratoria, Interim Controls, Time Phasing}

Implicit in any delay strategy is the understanding that some condition relevant to new development is expected to change in the future and that to permit continued development under existing regulations may in some way be adverse to public welfare. One example is the interim controls Lake County must enforce while it prepares its new general plan. The quite reasonable fear is that, because the new plan is anticipated to be more restrictive than the old one, landowners and developers will rush to obtain construction permits while the more lenient old controls prevail-controls now recognized as inadequate and defective on many counts. Mendocino County is under a moratorium for the same reasons, having declined so far to formulate interim controls.

Another frequently used example of delay strategy is moratoria or time phasing based on adequacy of public facilities-sewer systems, for instance. In the typical case, the rate and location of development is tied to a plan for public capital investment in a circular sequence: development is confined to areas where adequate services exist, and services are provided to areas that are timely for development. In other cases, local governments favoring slow or no growth have implemented only the former step. However, to ensure against undue or arbitrary restraint, the developer is often allowed to provide the required services or substitute a cash payment. ${ }^{28}$

A strategy of delay is obviously relevant to geothermal development in regard not only to the general plan but also to a county geothermal element, should one be undertaken. But we do not see any other impending changes to justify such measures, at least that can be anticipated today. The characteristics that result in land-use conflicts-namely, areal coverage, surfacial disturbance, and visual impact-are intrinsic under present technologic and economic conditions. Except for an occasional access road, geothermal development itself is largely independent of public services. However, the binary-cycle technology for liquiddominated reservoirs would require an external water source that may have to come from a public system. Of course, adequacy of public facilities is directly relevant to any residential or other development that geothermal development may induce. Lastly, a seriously underbudgeted government could conceivably make a case for delay on the grounds of regulatory incapacity; however, because permit fees can be adjusted to compensate for regulatory costs, we doubt such a rationale would hold up if contested.

\section{MARKET ALTERNATIVES}

All the above control methods are nonmarket in nature, that is, they involve government adopting regulations and enforcing them directly. To date, government action on behalf of the environment in the U.S. has been almost entirely nonmarket. Although such methods have a number of problems in general, 29 two are particularly key to environmental policy:

- The creation of regulations, whether by elected body or a delegated agency, is heavily influenced by personal subjectivity. Motives and incentives are not explicit, and hence decisions are far more prone to manipulation by interest groups at the expense of the general public.

- On the other hand, beyond the cost of adopting and enforcing them, as a rule government is not liable for the economic impacts of its regulations (see above, The Taking Question) and can thus act with impunity in decisions that can involve substantial private resources.

Central to both problems is that regulation can be manipulated to confer benefits without cost. In the first case, a company or industry may avoid large expenditures on impact mitigation by comparatively minor outlays on individual persuasion and public relations campaigns. In the second case, even when government acts in honest behalf of its citizens, it may impose regulations favored by those citizens only because they do not have to bear its costs, at the expense of the landowners and developers who do. (We must point out that this is an economic and not a legal argument, and not one we necessarily endorse.)

Economists, in general biased in favor of market solutions, have devised a number of alternatives to environmental regulation. However, most require that standards be set in advance and are thus as subject to the above problems as is regulation itself. We will examine one type that is not, the auction of rights to lower environmental quality. 
Imagine that ownership of a resource is vested in a public corporation distinct from the local or regional governmental unit, which has the power to auction off all rights to use the resource. The rights to reduce its environmental quality are put up for auction, with industry and, say, the county vying with one another. When the first unit is put up for bid, industry may outbid the county because the cost of the last unit of mitigation will be high for industry, but a small initial reduction in quality will not be of great importance to the people of the county. The second and some subsequent rights may also be won by industry, but ultimately, as the value of successive rights decreases for industry and increases for the county, industry will be outbid. At this point the auction ceases, because industry cannot skip a level of mitigation. Industry would be required to pay the public corporation for all units it purchased, the revenues being used to mitigate or otherwise compensate for the impacts to which it has acquired rights. The county would be required only to pay for the last, and as a rule cheapest, unit. $^{29}$

The above system, as may be obvious, was designed with air and water emissions in mind, impacts that can be easily measured and mitigated to any of several levels. In the case of geothermal land use, however, the features of a project that influence the magnitude of its impacts are largely fixed by technology and resource quality. Even so, in most instances the system could be adapted to some extent. For example, the disruption of faunal ecology by geothermal activity could largely be avoided by burying the steam lines which, although three to five times as expensive, is feasible. ${ }^{30}$ Its adverse visual and recreational impacts could be mitigated in part by more careful and generous revegetation of cleared land, etc.

A more troublesome aspect of such a markettype device to us is that a poor, sparsely populated county could not afford to compete with an industrial giant determined to develop a large energy resource. Aside from the moral question of whether power to regulate land use should depend entirely on ability to pay, the practical result of such a device in such a county would be minimal control at best, given the limited funds the county could draw upon. On the other hand, partial reliance on a market-type device has more promise. If the most precious aspects of the county or regional environment are protected by regulation, a device such as described above may be used to control the balance of development, where the impacts posed are undesirable but not catastrophic. One conceivable advantage of such a procedure is that the other actors, namely regional, state, and federal government, and even private advocate groups, could participate in the auction to reflect the fact that land resources within the county may have value to groups other than developers and county residents.

\section{FUTURE WORK}

This study is one component of the LLNL/LBNL Social and Economic Research Program for The Geysers-Calistoga KGRA, described in the LLNL report of the same name. ${ }^{31}$ The whole program is summarized in Fig. 10; this study comprises Work Products 1 and 4.

Work under the program in Fiscal Year 1979, that is, through September 30, proceeded along two parallel tracks through Products 3 and 4, respectively; the tracks converge in Fiscal Year 1980. For each projection of geothermal development chosen to be analyzed, we will use the economic and demographic forecasts to estimate quantitative land and infrastructure demand. These will be integrated with data on land-use conflicts to develop potential land-use configurations for each projection, i.e., the consequences of alternative levels of development for the land resource. We will then analyze those potential configurations for their land use and demographic, economic, and fiscal/infrastructural impacts.

Once we identify significant impacts and alternative mitigation policy options, local representatives will evaluate those options for their efficacy and their effect on geothermal and other development. The final outcome of this process, we hope, will be some optimal combination of development and environmental conservation that can be used as a basis for local, State, and Federal regulation.

One last point: although the remainder of the program covers all four counties in the KGRA, the land use component was limited to Lake County because we only had enough money for studying one, and for reasons explained earlier, Lake County 
was our top priority. However, the methodology and computer technology we used are not revolutionary, and any agency that so desired could, we are sure, duplicate part or all of the study for its own area of interest. Toward that end, we endeavored to make our own procedures as explicit as we could.

\section{ACKNOWLEDGMENTS}

We are most indebted to our consultants, Bill Derrenbacher, Jack Dangermond, and the people at ESRI who, faced with an unreasonable time frame, showed incredible class, and Brian Parker, whose expertise in the regional environment proved invaluable time and again. We also want to extend special thanks to Ray Mostin, Walt Wilcox, Deborah Israel, Carol and Jim Shepherd, Mary Jadiker, and George Voelker for their gracious help and counsel that were fit, we know, into busy schedules. 


\section{REFERENCES}

1. K. O'Banion, C. Hall, and K. Haven, Land Use Conflicts in The Geysers-Calistoga KGRA: a Preliminary Study, Lawrence Livermore Laboratory, Livermore, CA, UCRL-83666 (1979).

2. An Environmental Overview of Geothermal Development: The Geysers-Calistoga KGRA, Lawrence Livermore Laboratory, Livermore, CA, UCRL-52496, Vols. 1-8 (1978).

3. Board of Supervisors, County of Lake, Resolution \#79-200 (3 July 1979).

4. C. Shepard, Policy Recommendations from the General Plan Advisory Committee, memorandum to Lake County Board of Supervisors (23 April 1979).

5. K. Haven, V. Berg, and Y. Ladson, Local Population Impacts of Geothermal Energy Development in The Geysers-Calistoga KGRA Region, Lawrence Berkeley Laboratory, Berkeley, CA, LBL-10150 (June 1980).

6. R. K. White, R. E. Freeman, D. R. Myers, K. T. Semrau, J. L. Jones, R. E. Ruff, and L. A. Cavanaugh, Environmental Analysis for Geothermal Energy Development in The Geysers Region, Vols. 1-3, Stanford Research Institute, Menlo Park, CA, EGH-5554 (1977).

7. R. Helm, B. Neal, and L. Taylor, A Fire Hazard Severity Classification System for California's Wildlands, California Division of Forestry, Sacramento, CA (1973).

8. Report and General Soils Map, Lake County, California, U.S. Soil Conservation Service, Davis, CA (1973).

9. California Public Outdoor Recreation Plan, California Department of Parks and Recreation, Sacramento, CA (1974).

10. G. Whitaker and R. McCuen, "A Proposed Methodology for Assessing the Quality of Wildlife Habitat," Ecological Modeling 2, 251-272 (1976).

11. A Vegetation and Wildlife Habitat Mapping, Comarc Design Systems, San Francisco, CA (1975).

12. Areas of Special Biologic Importance, Lake County, California (map), California Department of Fish and Game, Sacramento, CA (1979).

13. Final Environmental Statement for the Geothermal Leasing Program, Vol. 2, U.S. Department of the Interior (1973).

14. Western Energy Resources and the Environment: Geothermal Energy, U.S. Environmental Protection Agency, EPA-600/9-77-010 (1977).

15. R. H. Twiss and N. W. Twiss, Aesthetic and Land Use Impacts of Five Alternative Transmission Line Corridors from the Geysers Geothermal Field to Northem San Francisco Bay Load Centers, Lawrence Livermore Laboratory, Livermore, CA, UCRL-15246 (1980).

16. California Public Resources Code, sec. 25500 (1974).

17. 42 U.S.C.A. sec. 4201 (1969).

18. D. Hill, California Energy Resources Conservation and Development Commission (1979) and B. Larramendy, U.S. Bureau of Land Management (1979), private communication.

19. County of Lake Geothermal Policy Statement (9 July 1979).

20. 58 Ops. Atty. Gen. 729 (31 October 1975) (State).

21. Geothermal Advisory Committee to CERCDC, Final Report (January 1979).

22. U.S. Constitution, Amendment V.

23. Pennsylvania Coal Company v. Mahon, 260 U.S. at 415 (1922).

24. F. Bosselman, D. Callies, and J. Banta, "The Taking Issue: A Study of Constitutional Limits," in Management and Control of Growth, R. Scott, Ed. Urban Land Institute, Washington DC, 1975, Vol. 1.

25. California Government Code, secs. 65100-65700.

26. Hahn, Wise, and Associates, Conditions, Procedures, and Performance Standards for Geothermal Regulation, County of Lake (13 April 1972).

27. (draft) M. Jadiker, B. Woods, N. Stoelson, K. Neasham, T. Closser, C. Larson, and D. Hill, Geothermal Resource Development Policy, Conditions, and Performance Standards, County of Lake (10 May 1979). 
28. R. Einsweiler, M. Gleeson, I. Ball, A. Morris, and D. Sprague, "Comparative Descriptions of Selected Municipal Growth Guidance Systems: A Preliminary Report," in Management and Control of Growth, R. Scott, Ed. (Urban Land Institute, Washington, DC 1975), Vol. 2.

29. D. Savage, M. Burke, J. Coupe, T. Duchesneau, D. Wihry, and J. Wilson, The Economics of Environmental Improvement (Houghton Mifflin Co., Boston, MA, 1974).

30. Gennis and Associates, Final Environmental Impact Report: East Ford Flat Geothermal Project, Lakeport, CA (April 1979).

31. C. Hall and K. O'Banion, Social and Economic Research Program for The Geysers-Calistoga KGRA, Lawrence Livermore Laboratory, Livermore, CA, UCRL-52763 (1979). 


\section{Data Sources}

-M. Z. Meidav, "Direct Heat Applications of Geothermal Energy in the Geysers/Clear Lake Region", Geotherma Energy Magazine, vol. 7, no. 5, pp. 18-24.

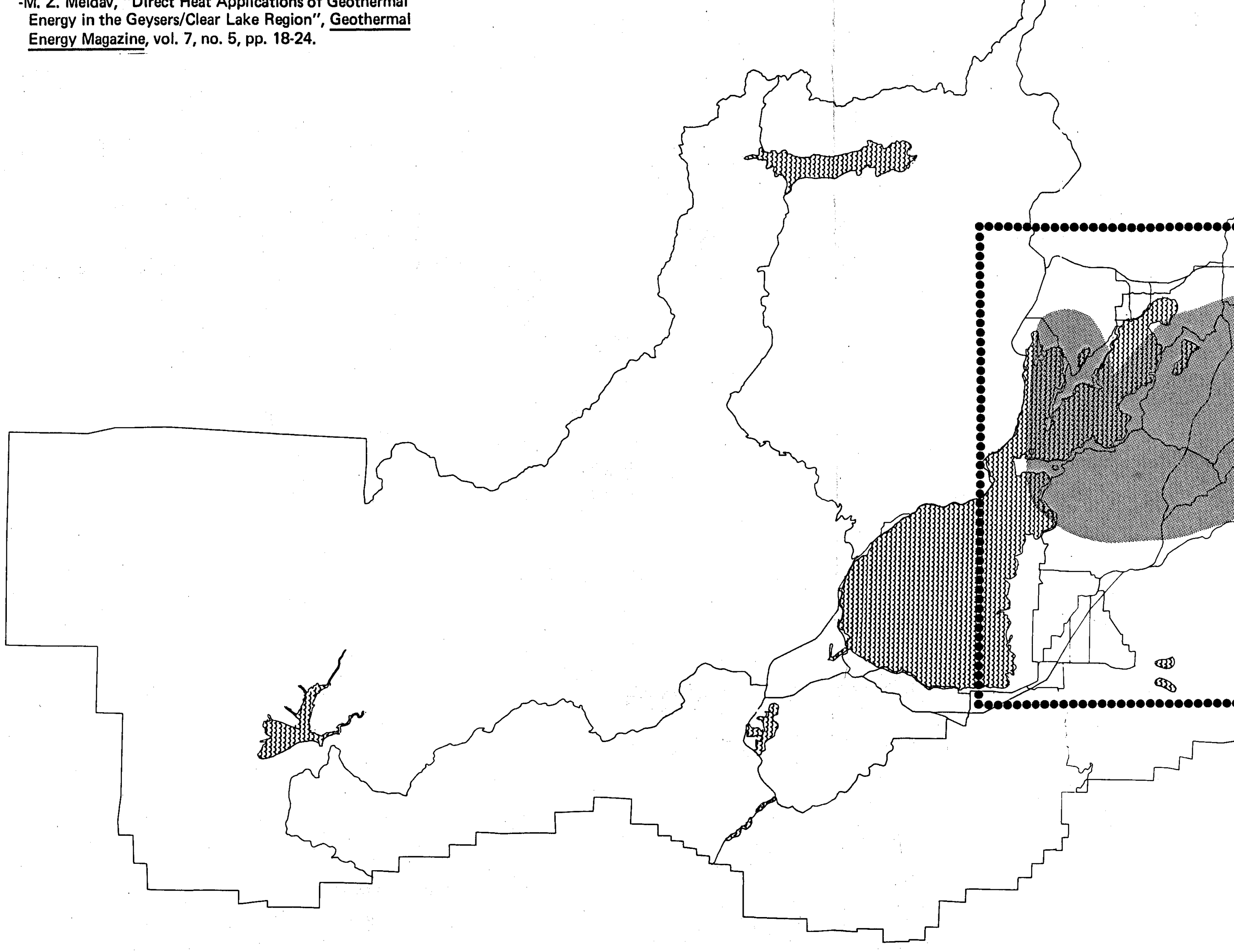


Settlement/Developed

Concentrated Residential/

Transportation/Other Developed

Dispersed Residential

Extractive

Geothermal Wells and Plants

Agriculture

Field, Row and Feed Crops

Vineyards and Orchards

Dry Farming/Improved Rangeland

Natural Land/Water

$\begin{array}{rr}5,500 & 2 \\ 600 & <1 \\ 300 & <1 \\ 200 & <1 \\ 10,500 & 3 \\ 7,000 & 2 \\ 5,400 & 2 \\ 318,100 & 91\end{array}$

Data Sources

USFWS Black and White Aerial Imagery $(1: 80,000)$

-USFS Soil-Vegetation Maps of California $(1: 31,680)$

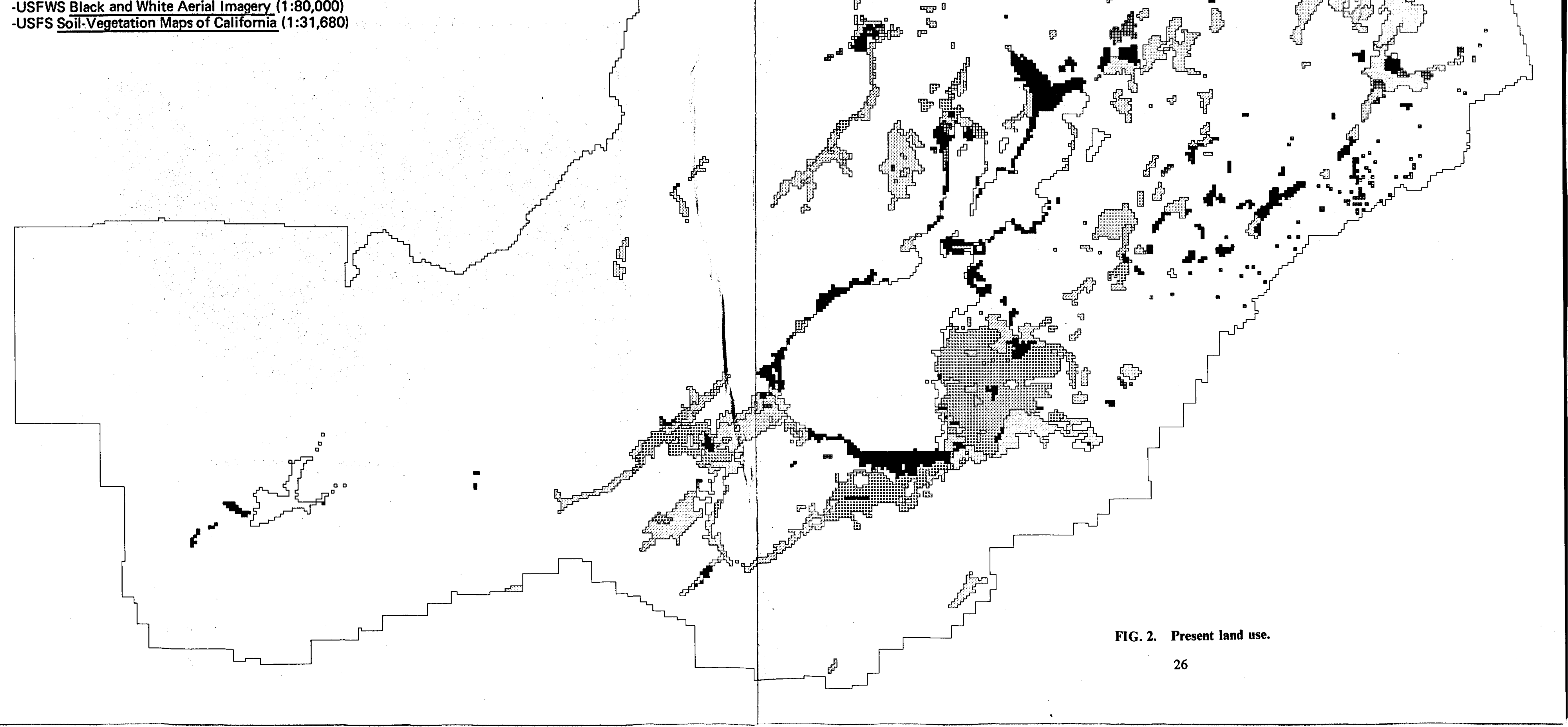




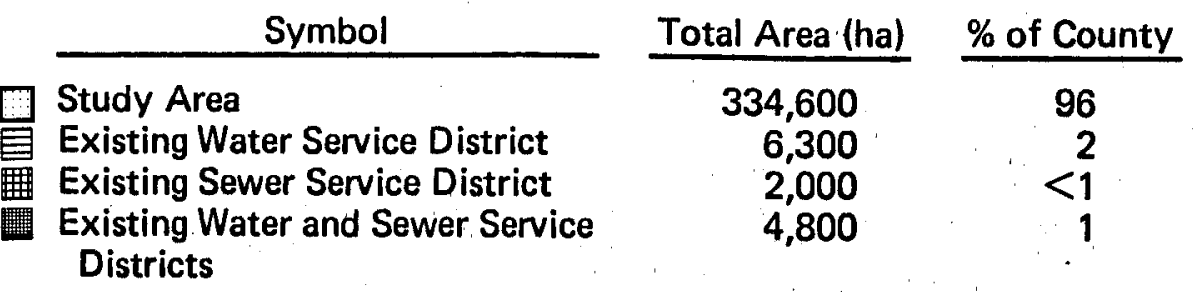

Data Sources

Lake County Clear Lake Basin Plan

FIG. 3. Sewer and water service districts.

27 


\begin{tabular}{|c|c|c|}
\hline Symbol & Total Area (ha) & $\%$ of Count \\
\hline $\begin{array}{l}\text { Class I - II } \\
\text { Class III }\end{array}$ & 17,000 & 5 \\
\hline $\begin{array}{l}\text { Adjacent to Class I- II } \\
\text { Not Adjacent to Class I II } \\
\text { Classes IV - VIII }\end{array}$ & $\begin{array}{r}5,200 \\
9,700 \\
297,000 \\
18,900\end{array}$ & $\begin{array}{r}2 \\
3 \\
85 \\
5\end{array}$ \\
\hline
\end{tabular}

Data Sources

-USSCS Report and General Soil Map, Lake County, Ca.

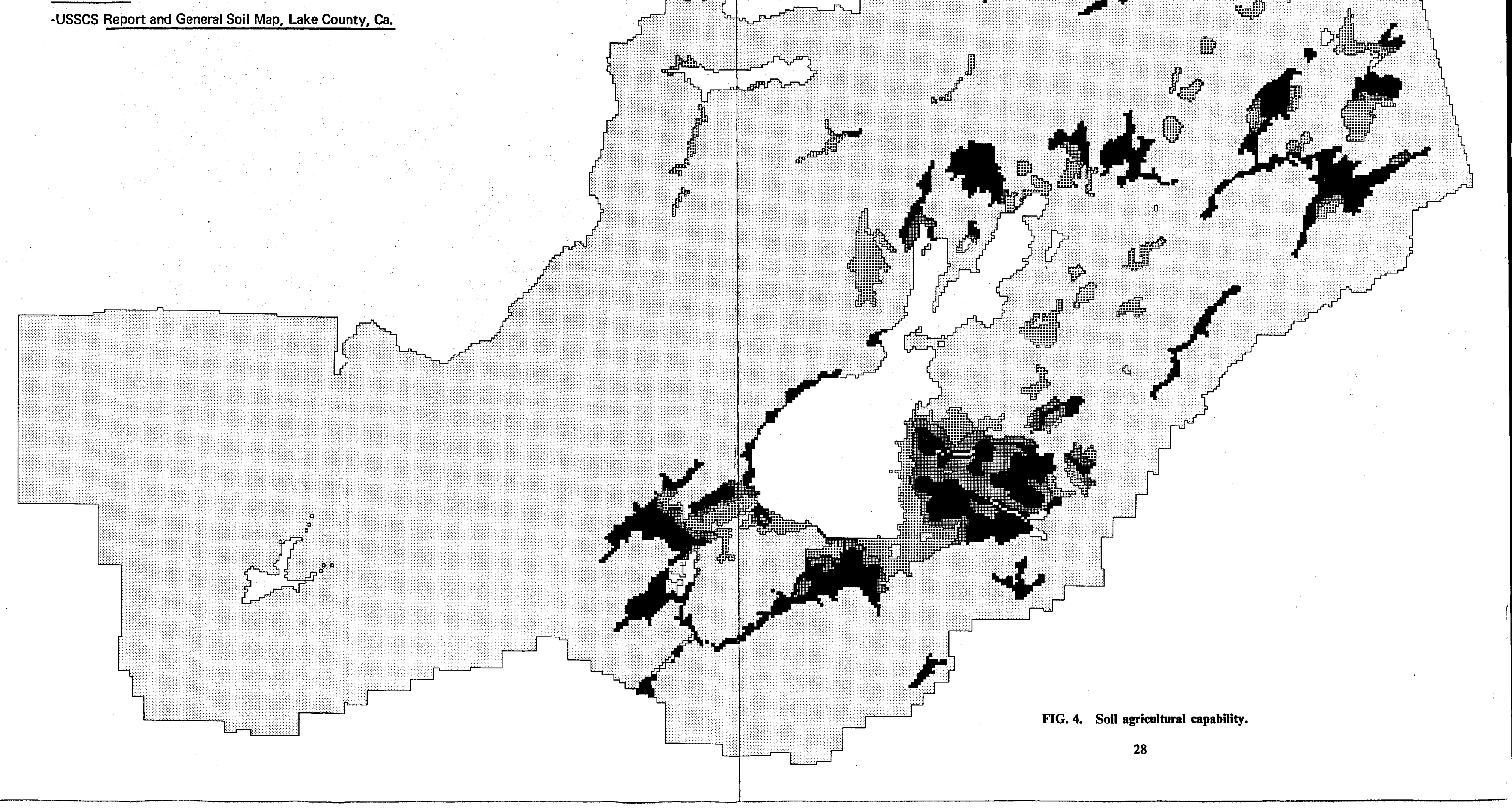




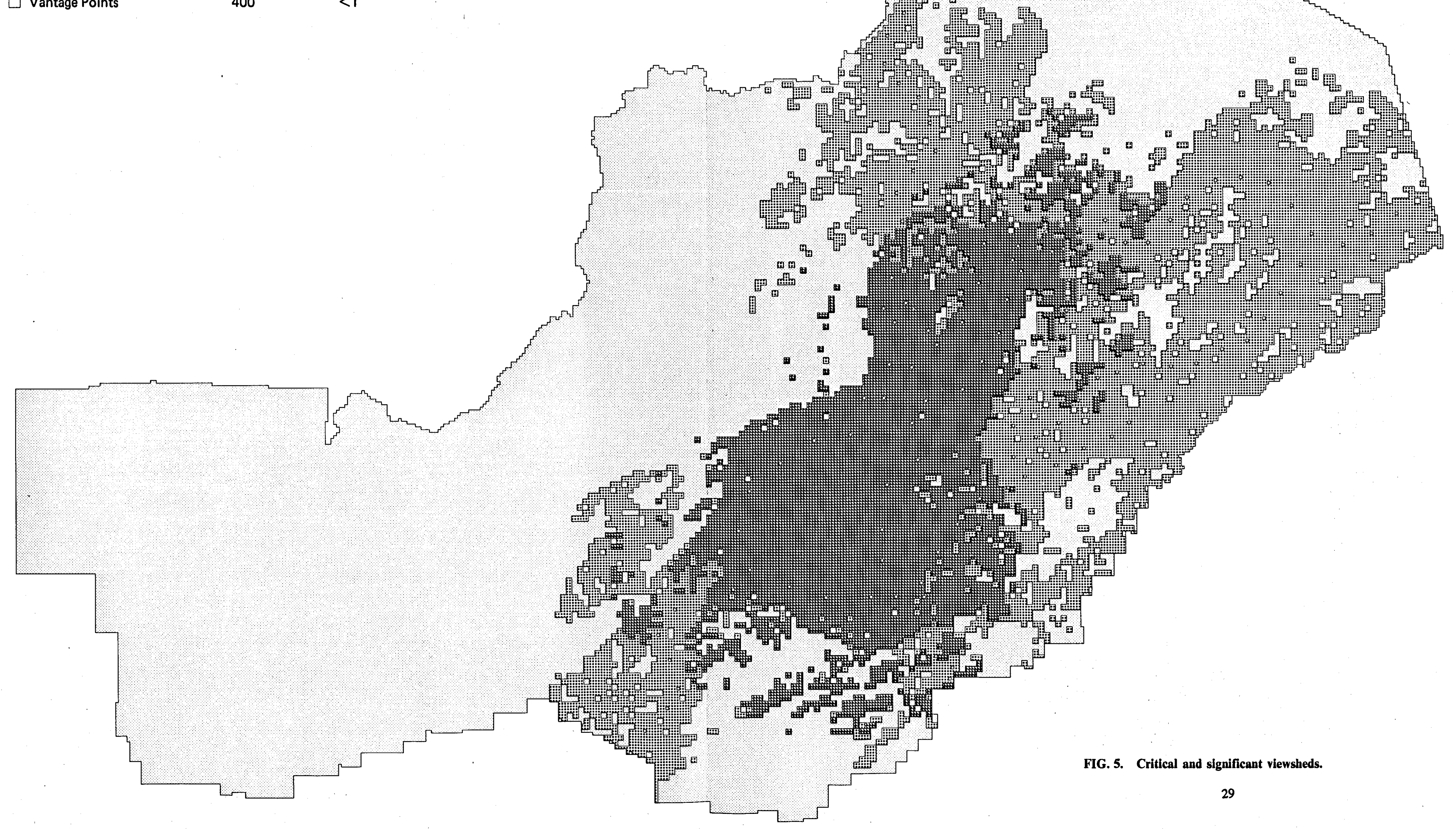


Symbol

Mendocino National Forest

Bureau of Land Management Lands

State Parks and Forests

Other Public Lands

$\checkmark$ Private Lands

Total Area (ha)

106,900

106,900
52,100

3,000 .

4,400
400

180,700

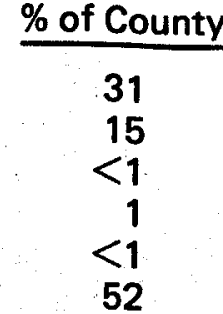

Data Sources

-USBLM, Land Status Maps, Lakeport, Willows and Healdsburg Sheets

(1:100,000)

USBLM, Land Status Map, Cow Mountain Planning Unit

31
15
$<1$
1
$<1$
52

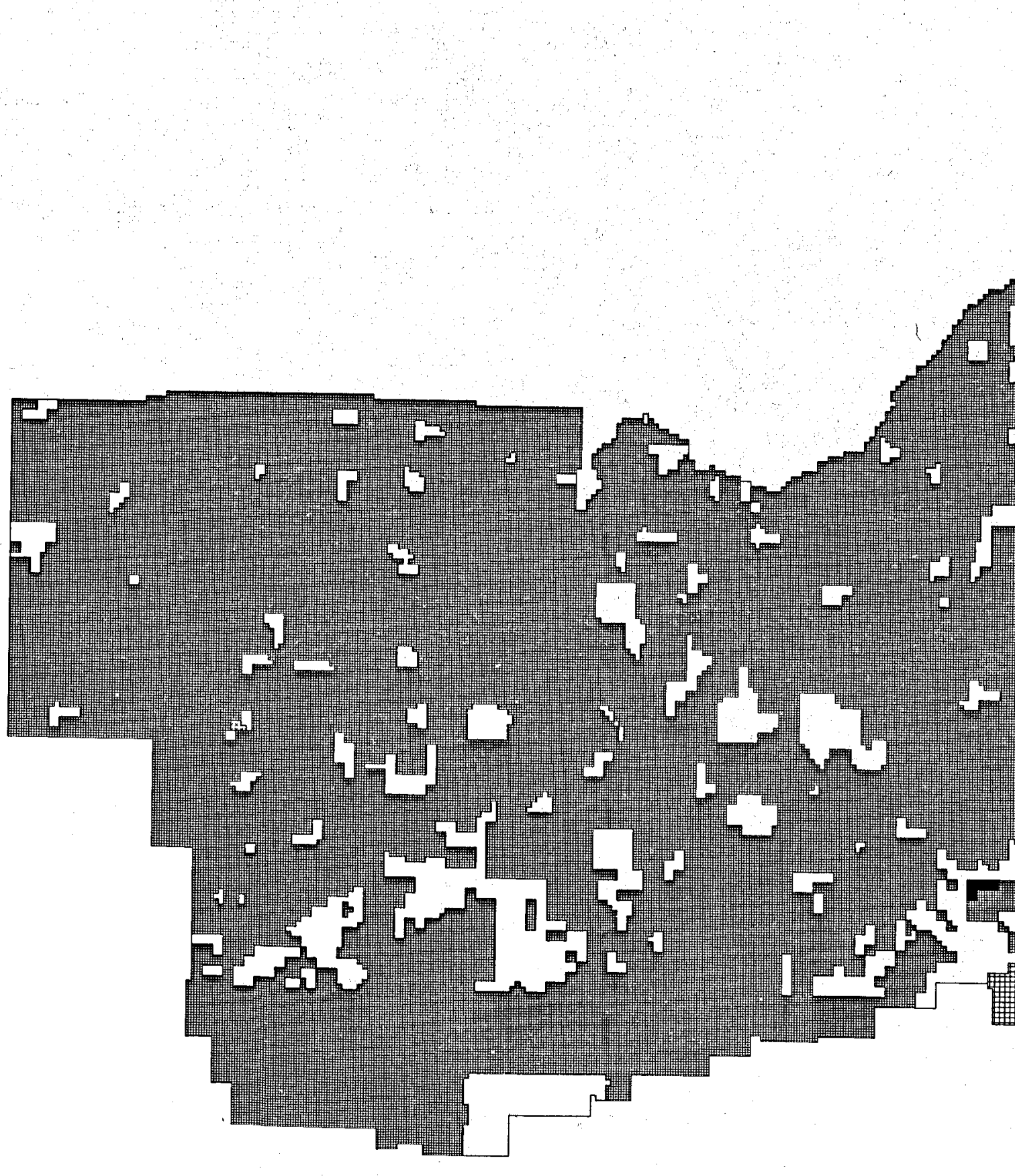

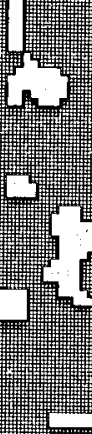

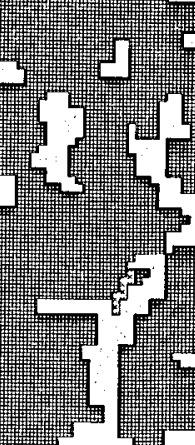

(2)
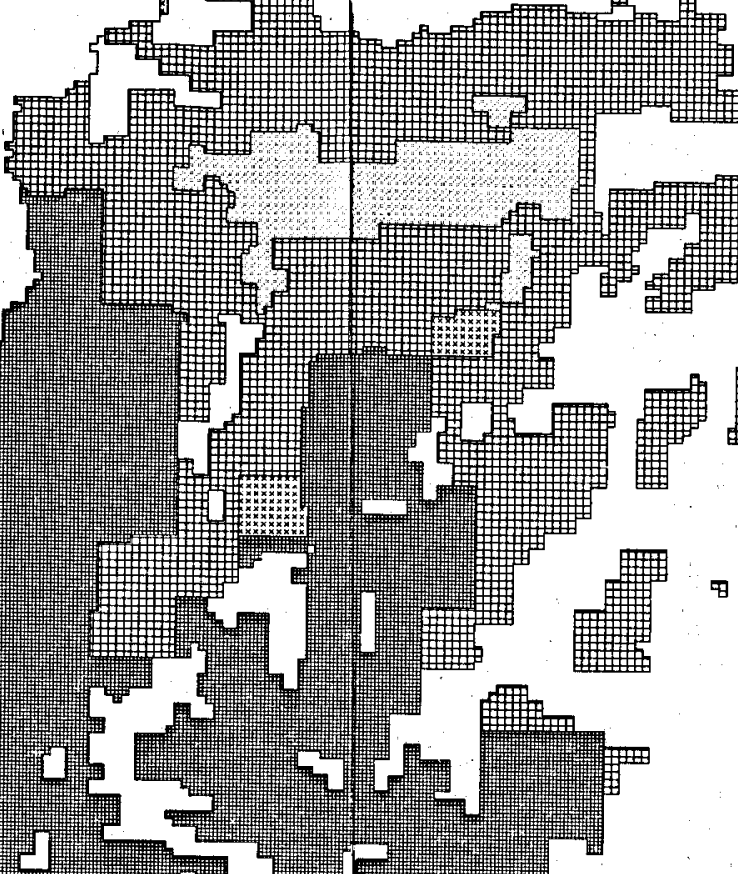

耛

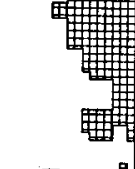

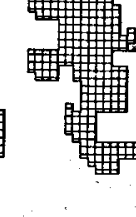

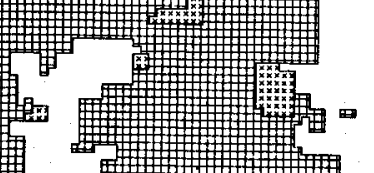

要裙

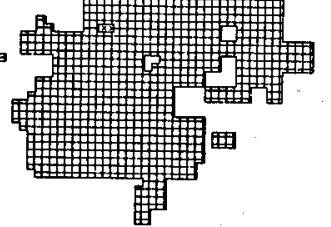

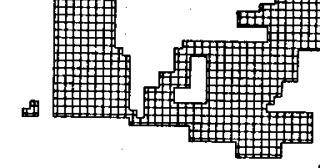

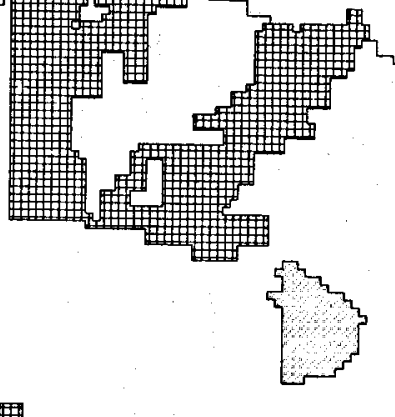

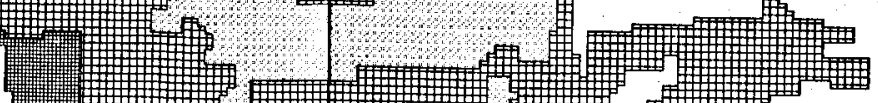

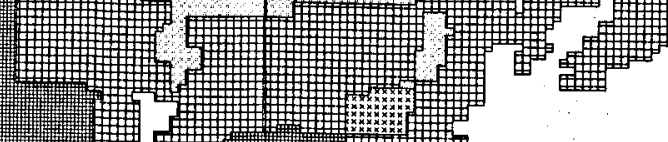

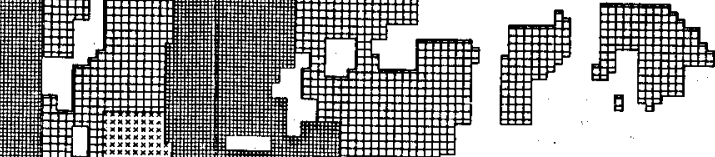

F

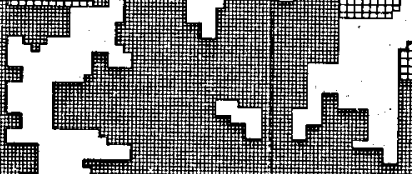

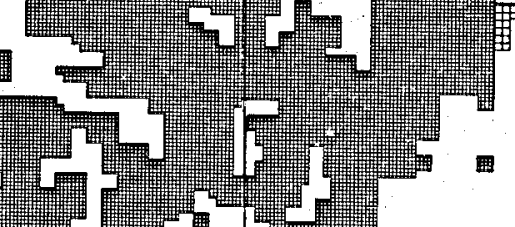

震

minting

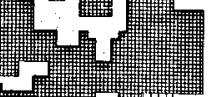

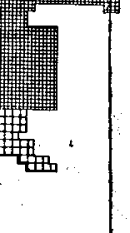

由

需量

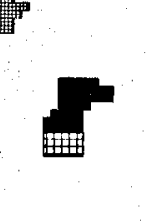

要题
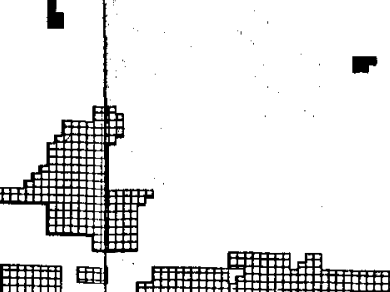

. э. 田 要

四 


\section{Symbol}

ASBI: Rare or Endangered Species ASBI: Critical Habitat ASBI: Key Wildlife Area Riparian Area Ecotonal Area

Data Sources

-CDFA Report and Maps of Areas of Special Biological Importance, Lake County, $\mathrm{Ca}$

\begin{tabular}{ccc} 
Total Area (ha) & & \% of County \\
\cline { 1 - 1 } 704 & & $<1$ \\
3876 & & 1 \\
42208 & & 12 \\
73596 & & 21 \\
77244 & 22 \\
150140 & & 43
\end{tabular}
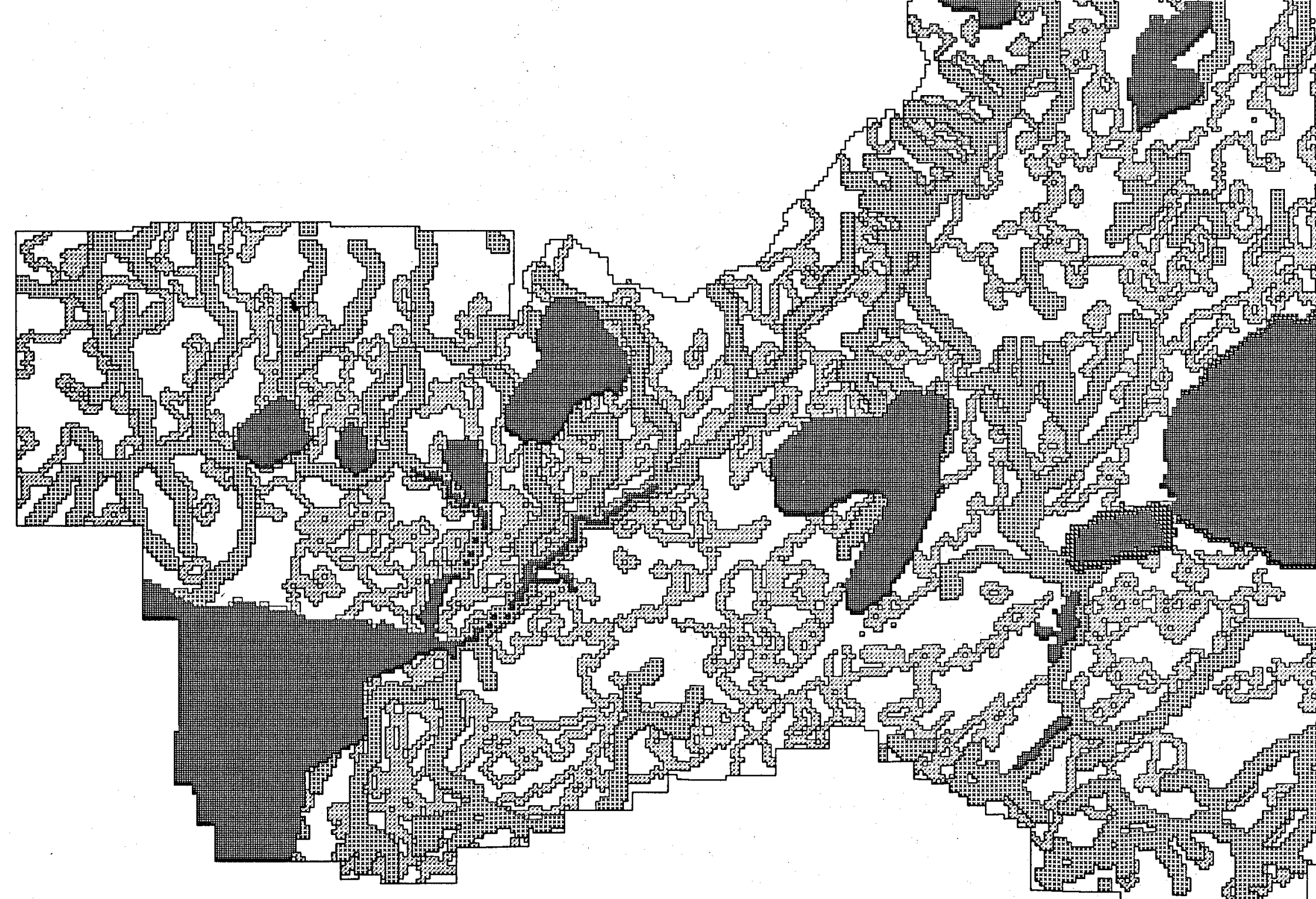

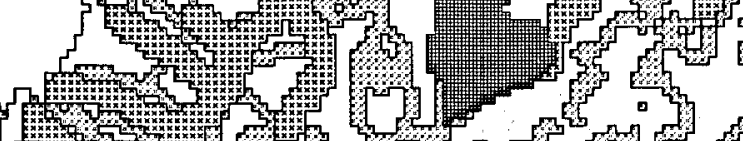

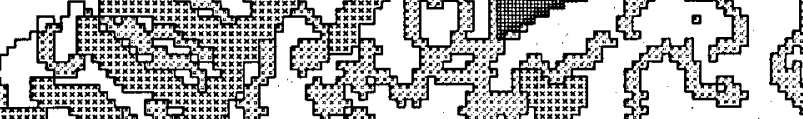
$\checkmark$

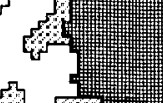
, F

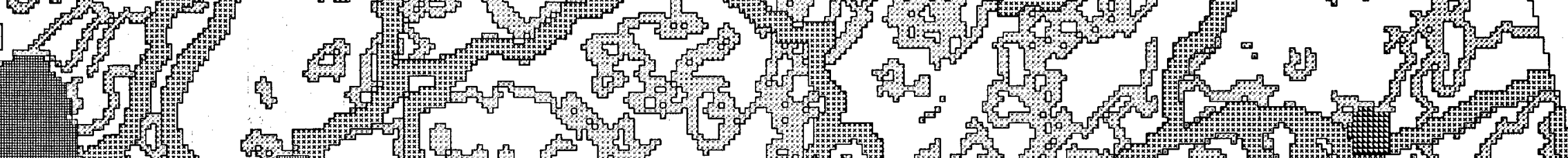
,

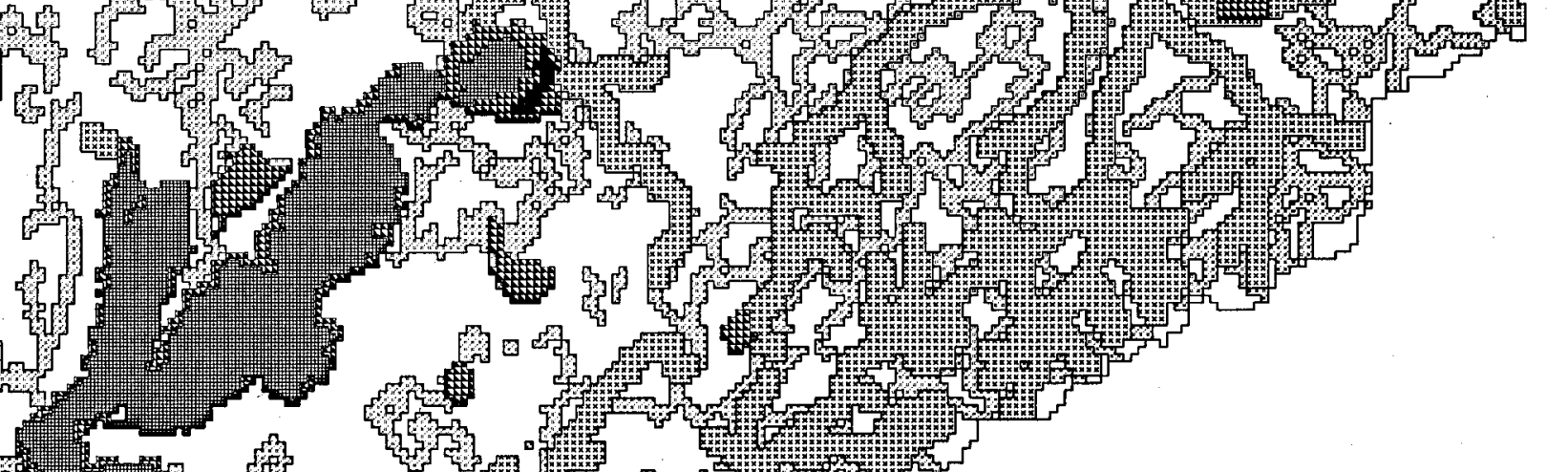

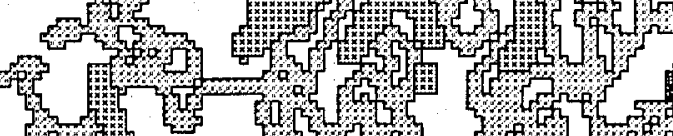

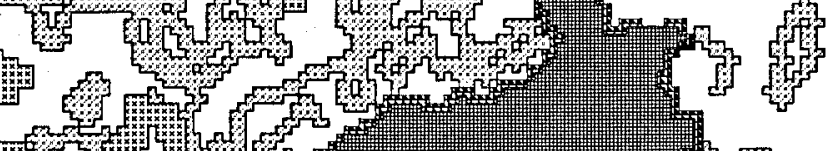
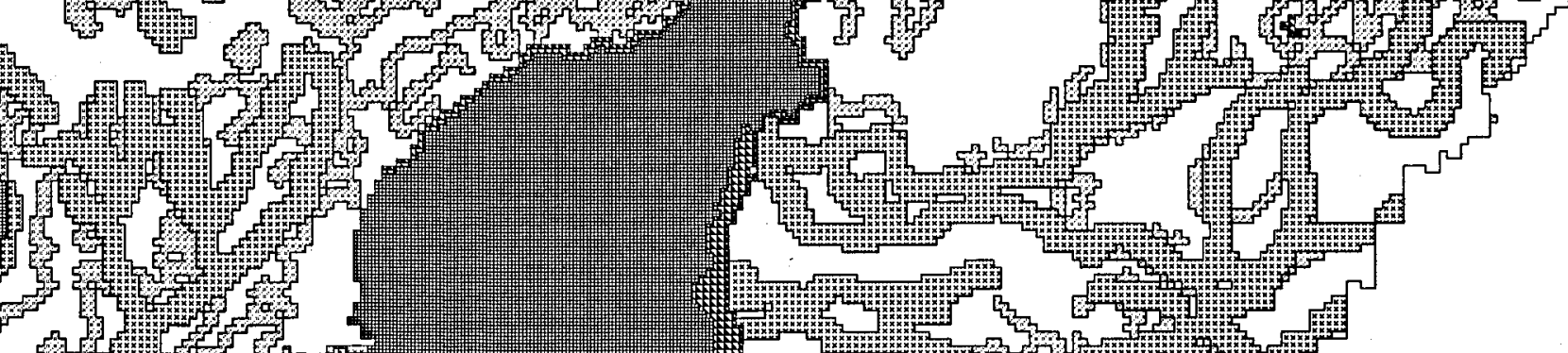

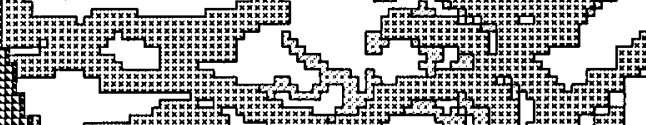
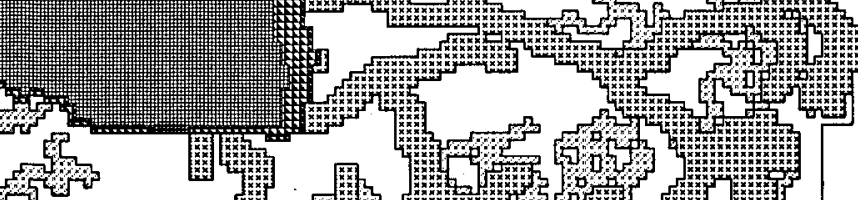

Hed

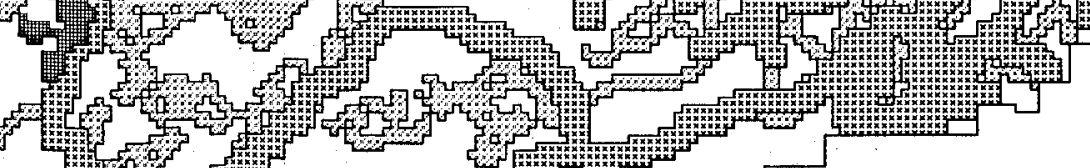

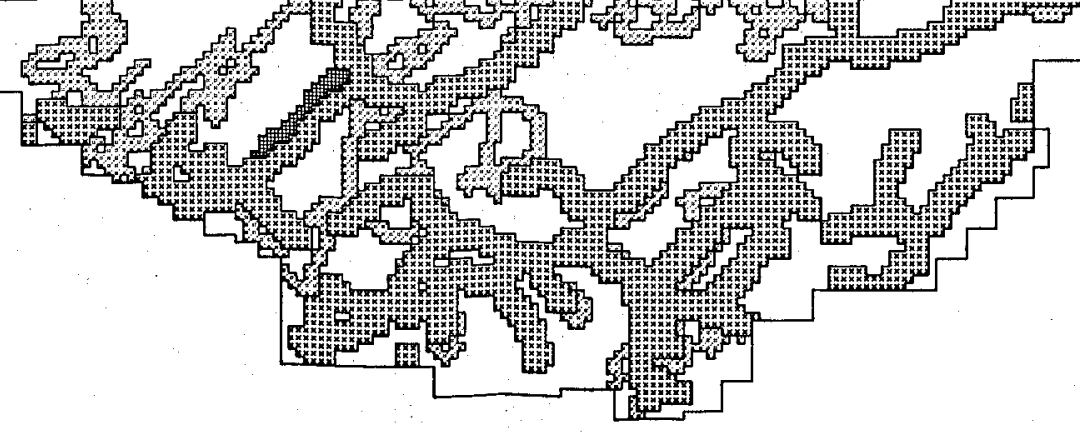

FIG. 7. Areas of ecological value. 
$\square$ ASBI, Prime Cropland, Critical Viewshed,

or Water

Ecotonal Area

Significant Viewshed

No Conflicts

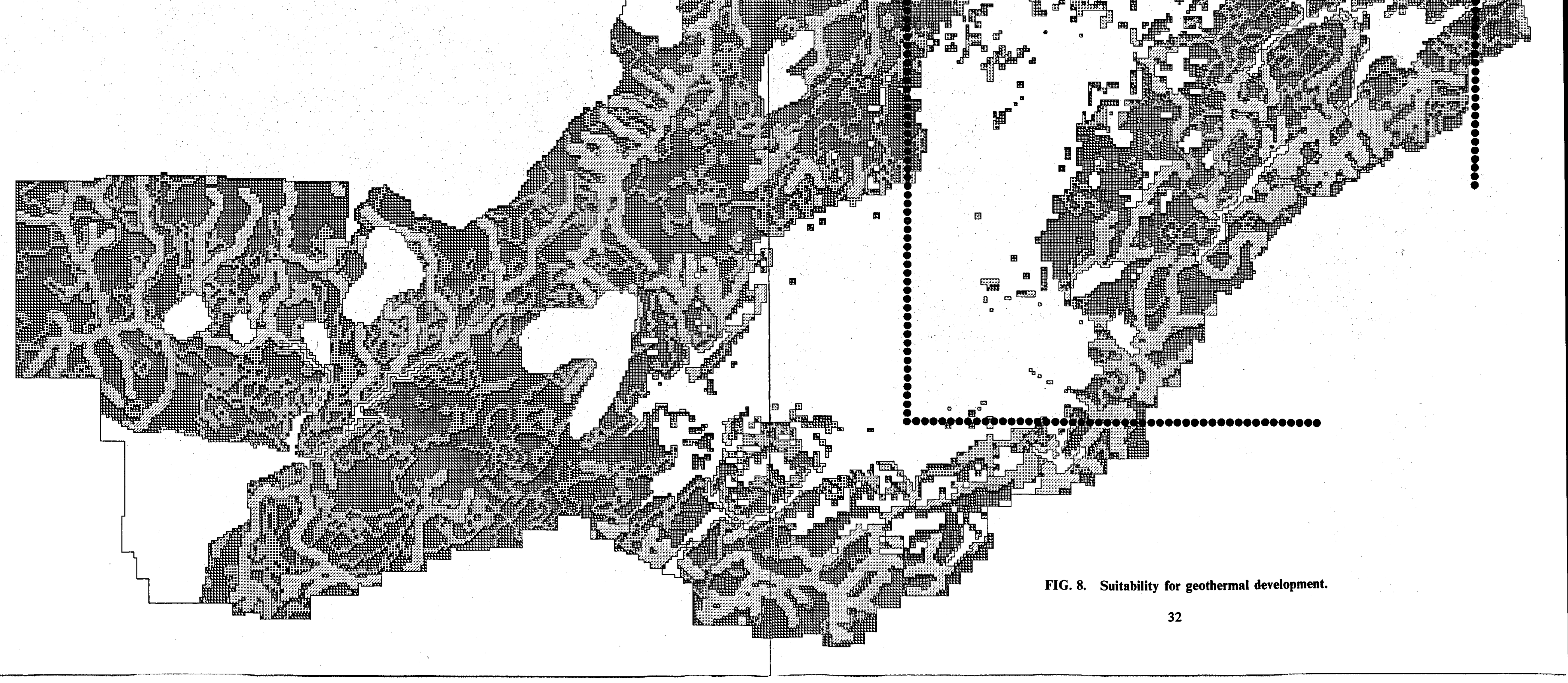




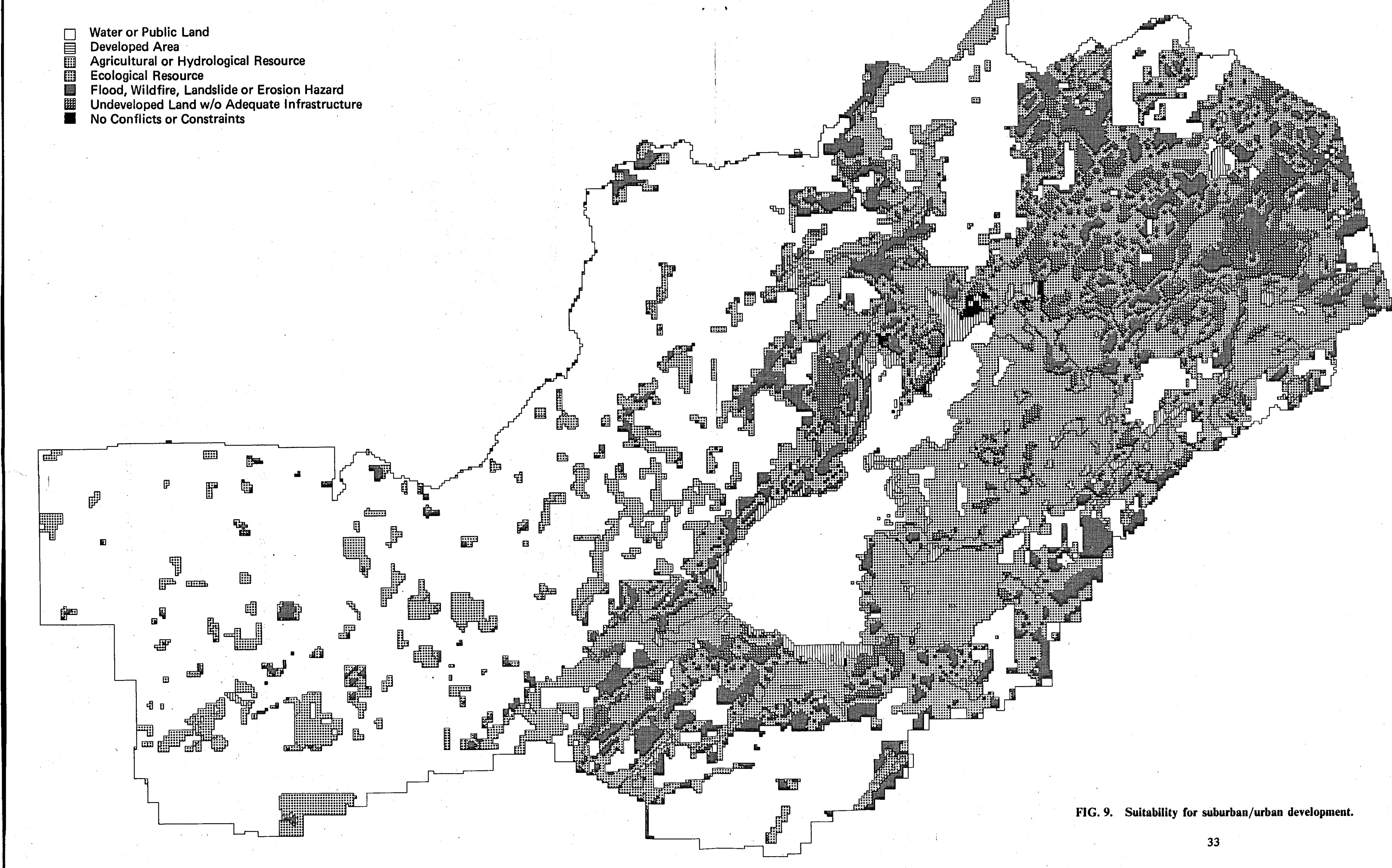


Constraints
(legal, political,
technological) $\quad \begin{gathered}\text { Local criteria } \\ \text { for land- } \\ \text { development }\end{gathered}$

Land and

infrastructure $/ 1$

capability

land uses

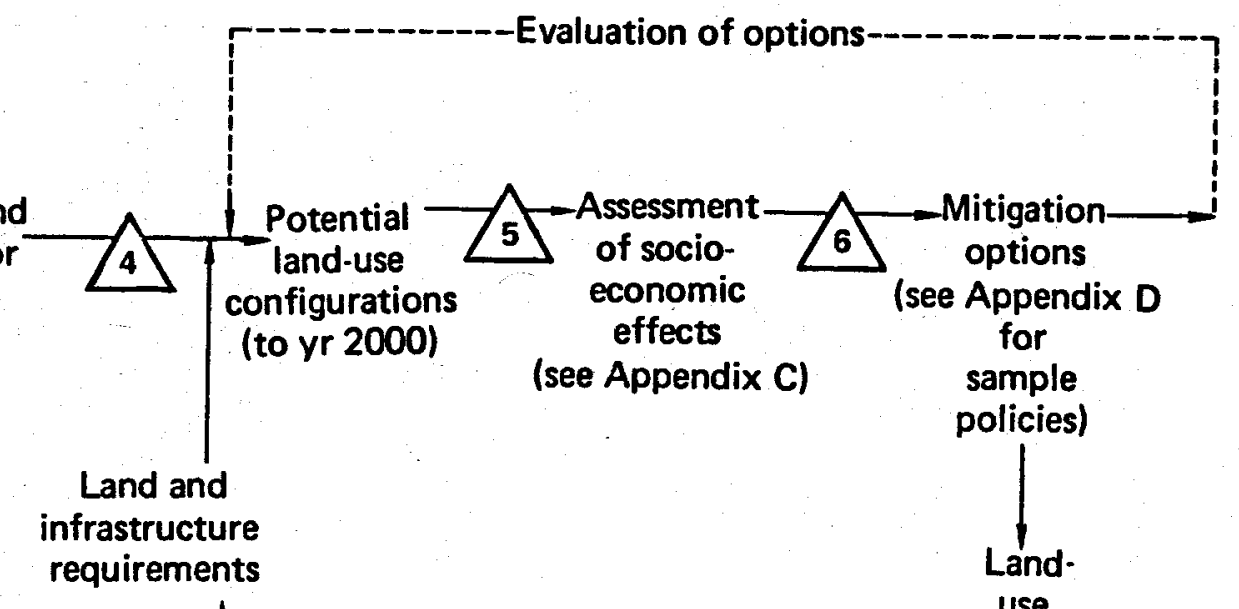

$\stackrel{\omega}{\ddagger}$

(see Appendix B)

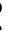

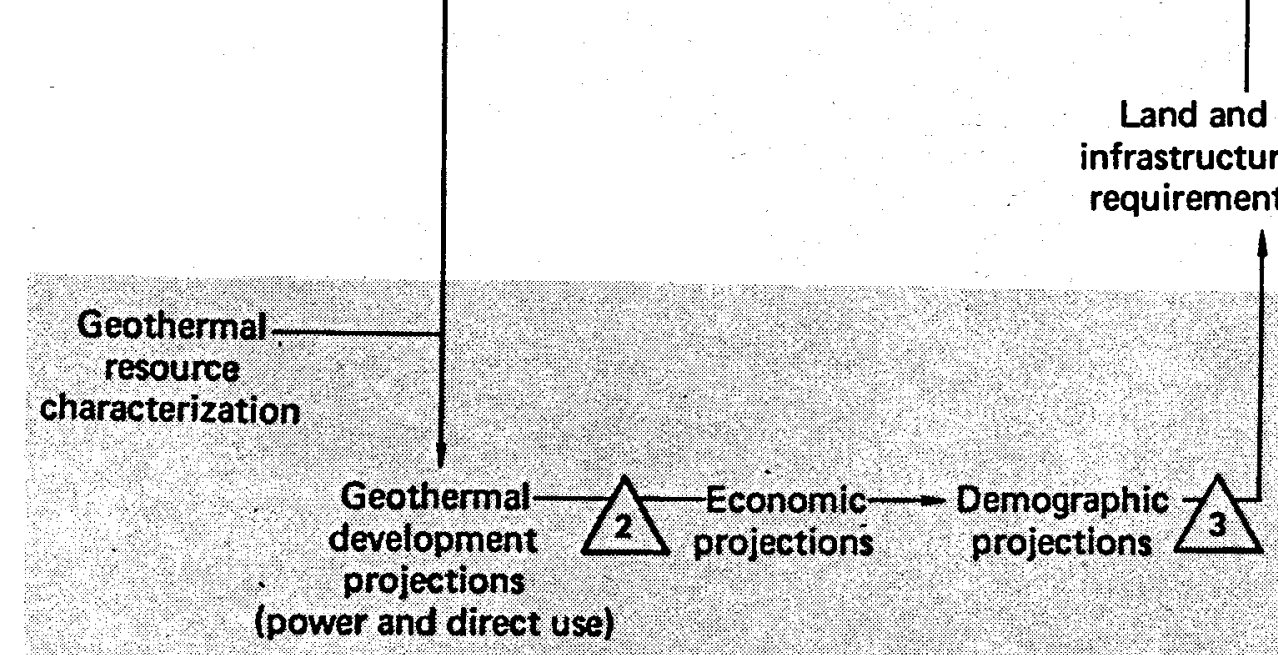

$\Lambda=$ Products (See work unit)

outcomes

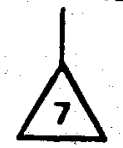

FIG. 10. Diagram of social and economic research program. 